\title{
Abnormal serum uric acid levels in health and disease: A double-edged sword
}

\author{
Christopher Ekpenyong*, Ernest Akpan \\ Department of Physiology, Faculty of Basic Medical Sciences, University of Uyo, Uyo, Nigeria
}

Email address:

chrisvon200@yahoo.com (C. Ekpenyong), akpansons2000@yahoo.com (E. Akpan)

To cite this article:

Christopher Ekpenyong, Ernest Akpan. Abnormal Serum Uric Acid Levels in Health and Disease: A Double-Edged Sword. American Journal of Internal Medicine. Vol. 2, No. 6, 2014, pp. 113-130. doi: 10.11648/j.ajim.20140206.15

\begin{abstract}
Abnormal serum uric acid (UA) level is a highly prevalent condition worldwide and is increasing in the general population. This alarming epidemiological trend has enormous public health implications due to the central role of abnormal serum UA levels in the initiation, progression, and long-term effects of many metabolic and systemic diseases. Metabolic disorders are major causes of global morbidity and mortality. Altered serum UA level, both above and below the reference ranges for individual traits and contexts, is potentially harmful and described by many researchers as a double-edged sword. Concrete prevention plans in susceptible individuals and treatments to restore normal levels in individuals already affected are advocated. Lifestyle adjustment, including regular moderate physical activity, weight management, healthy eating, and regular serum UA screening are recommended for individuals susceptible to derangement in serum UA levels due to age, sex, genetics, and other acquired conditions. Public health efforts to create awareness about the menace of abnormal serum UA levels, particularly in susceptible individuals, should be encouraged.
\end{abstract}

Keywords: Deranged Serum Uric Acid, Adverse Health Effect, Human

\section{Introduction}

Abnormal serum uric acid (UA) level is a major public health problem due to its pivotal role in the etiology of many systemic diseases. Epidemiological studies have identified serum UA level both below and above the reference range as a marker, independent risk factor, or both for metabolic and cardiovascular morbidity and mortality, a situation described as a double-edged sword [1].

Abnormal serum UA level is highly prevalent worldwide [2], and the number of people affected continues to rise [3]. This alarming epidemiological trend may herald a corresponding and imminent increase in associated complications, underscoring the need for urgent public health attention. Consequently, researchers have raised many questions about the mechanisms and causes of this derangement and its health consequences. Critics have partly blamed modernization for this trend, assuming that our ancestors may not have experienced many of the metabolic disorders present today. Our predecessors lived simple, less complicated lives, followed less risky lifestyle patterns, and ate simple yet nutritious diets and hence achieved longevity and were less prone to metabolic disorders. Most striking is the likelihood that our prehistoric ancestors had healthier serum UA levels, as was confirmed among the Yanomamo of southern Venezuela, who have average serum uric acid levels of $3 \mathrm{mg} / \mathrm{dL}$ [4] that may explain in part why they are less prone to diseases such as hypertension. The questions to be addressed include where have we gone wrong? Can we reverse the current trend? Can we conclude that the modern prevalence of abnormal serum UA levels in the general population is the central controlling factor in the etiology of disease conditions such as renal failure and cardiovascular, neurodegenerative, cerebrovascular, autoimmune, inflammatory, reproductive, musculoskeletal, endocrine, metastatic, and metabolic disorders? [1, 5-8]

This review addresses these questions.

\section{Synthesis and Transport of UA, an Indispensible Molecule}

UA is a weak acid (pka, 5.8) that is primarily found and distributed in the extracellular fluid compartment as monosodium urate, a final oxidation product of purine metabolism. When $\mathrm{pH}$ is $<5.75$, as may occur in urine, the predominant form is un-ionized uric acid [9], whereas at a $\mathrm{pH}$ 
of 7.4, the ionized form circulates. When UA reaches concentrations above $6 \mathrm{mg} / \mathrm{dL}$ (oversaturation), it has a high propensity for crystallization and precipitation of monosodium urate in urine, body fluids, and soft tissues [10]. Conversely, purines are products of dietary and endogenous nucleic acid metabolism, a pathway catalyzed by a number of enzymes. Specifically, UA is produced from xanthine via the action of xanthine oxidase, an enzyme that converts hypoxanthine to xanthine. Additionally, the activities of guanine deaminase, which converts guanine to xanthine, can also promote UA production. UA can be synthesized directly from 5-phosphoribosyl pyrophosphate and glutamine (Fig. 1) [11]. In the absence of uricase in humans, a more soluble compound, allantoin, is not produced, hence limiting the pathway to urate production and excretion in urine [11]. The amount of UA within physiologic fluid (synovial fluid/blood plasma), especially blood plasma, depends on three pivotal control points - namely, dietary purine intake, urate biosynthesis (uricolysis), and rate of urate excretion. Most of the UA generated daily is excreted from the kidneys (approximately 70\%) and the rest from extra-renal routes including the intestines, skin, hair, and nails $[12,13]$. UA is produced in the liver and intestinal mucosa [13] as well as in the microvascular endothelium at various sites such the mouth, airway, heart, and brain [14-16].

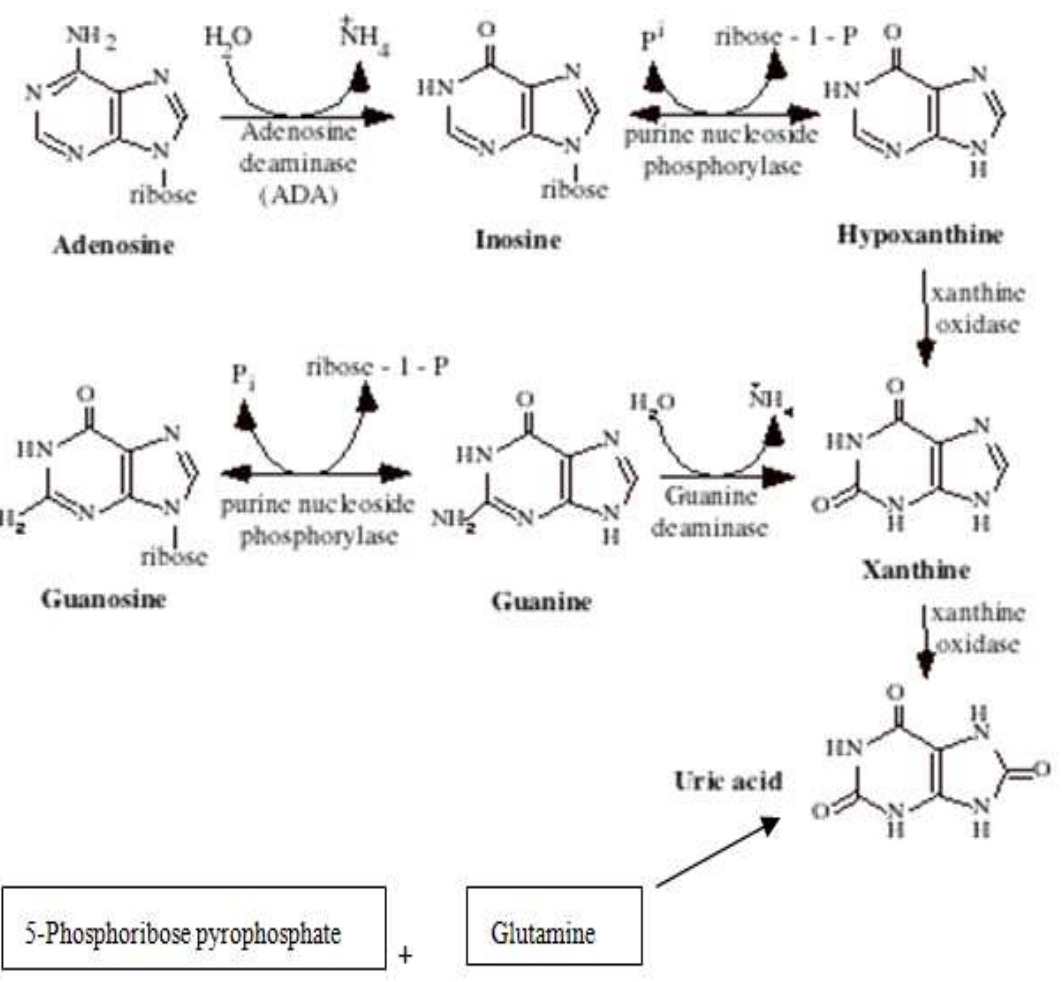

Figure 1. Pathway for uric acid synthesis

Various physiological mechanisms reportedly occur in the kidneys for tight control of plasma urate clearance via glomerular filtration, reabsorption, secretion, and post-secretory absorption [17]. However, some authors contest this aforementioned four-mechanism model and suggest a continuous and simultaneous reabsorption-secretion phenomenon along the tubular compartments [18].

In the kidney, approximately $90-95 \%$ of UA filtered at the glomeruli is reabsorbed from the proximal renal tubule, whereas active secretion into the distal tubule takes place through an ATPase-dependent mechanism [19]. A number of urate transporters, including human urate transporter (hURAT) 1 and hURAT2, are responsible for urate reabsorption, whereas organic anion transporters (OATs) such as $\mathrm{OAT}_{1}$ and $\mathrm{OAT}_{3}$ and the ATP-dependent urate export transporter- $\mathrm{MRP}_{4}$ (multiple drug resistant protein-4) are involved in urate secretion [20,21]. URAT1 is located on the apical tubular membrane. UA has low solubility in water and plasma, and persistent high serum UA levels predispose individuals to urate crystal deposition within soft tissues, an integral factor in the pathogenesis of gout [22].

To establish urate balance, the body manages the rates of urate production and excretion; therefore, any derangement in urate homeostasis results in abnormal serum UA level (hyperuricemia or hypouricemia), a condition that can be considered a double-edged sword in terms of its effects on the body in health and disease.

\section{3. "Normal" Serum UA Level}

Normal serum UA acid level is still being debated. In many countries, $7 \mathrm{mg} / \mathrm{dL}$ for men and $6 \mathrm{mg} / \mathrm{dL}$ for women are accepted as the upper limits of normal, and approximately 2 $\mathrm{mg} / \mathrm{dL}$ for men and women is the lower limit. However, these values have been adopted for individuals without clinical evidence of gout [10]. Some authors have proposed that a 
threshold of $<6.0 \mathrm{mg} / \mathrm{dL}$ should be adopted as the normal reference value for UA based not on the distribution of its circulating levels in the general population but on its physiological role and pathophysiological involvement in human disease[10]. In some individuals, levels slightly above this upper limit might be considered normal. The view is that serum UA concentration should be a range, but not fixed, and hence could vary from person to person. In other words, what is considered normal in one patient could be considered abnormal in another based on the outcome and not on the value. For example, Obermayr et al [23] stratified study subjects into three groups: those with normal UA levels $(<7.0$ $\mathrm{mg} / \mathrm{dL})$, modestly elevated UA levels $(7.0-8.9 \mathrm{mg} / \mathrm{dL})$, and markedly elevated UA levels $(\geq 9.0 \mathrm{mg} / \mathrm{dL})$.

Therefore, under physiological conditions and with minimal exposure to confounding factors, serum UA levels between 2 and $7.0 \mathrm{mg} / \mathrm{dL}$ in males and between 2 and $6.5 \mathrm{mg} / \mathrm{dL}$ in females could be considered normal [23-27]. Serum UA levels persistently below $2 \mathrm{mg} / \mathrm{dL}$ (hypouricemia) and above $7 \mathrm{mg} / \mathrm{dL}$ (hyperuricemia) for individual traits and contexts are considered abnormal and may predispose patients to metabolic deficits and disease complications. Another interesting fact is that serum UA levels vary across the menstrual cycle in most healthy premenopausal women, and in addition to estrogen, rising levels of progesterone can also induce uricosuric effects in women [28]. Hence, menstrual cycle should be considered when measuring serum UA in women.

Certain modifiable (e.g., lifestyle, physical activity, and diet) and unmodifiable (genetic/inherited or idiopathic) factors can shift UA levels from normal to abnormal. Many experts consider abnormal serum UA level to be the underlying cause of certain diseases, whereas others believe that it is only a consequence, indicator, or even predictor of underlying disease conditions. Yet others view it as an active participant, not an innocent bystander, in many disease entities. Still others see it as "a friend and a foe." Hence, abnormal serum uric levels might operate on a two dimensional effect principle in many disease conditions [6, 21, 24, 27].

Consequently, although abnormal serum UA levels have been regarded in recent studies as independent predictors of renal dysfunction in rheumatoid arthritis and congestive heart failure $[29,30]$ and as risk factors that precipitate complications in renal failure and many cardiovascular, neurodegenerative, cerebrovascular, autoimmune, inflammatory, and metabolic diseases [5-8], another school of thought is that these derangements could have some advantages - as measures of protection against long-term complications in some diseases and as targets for treatments in many neurological diseases. In effect, UA may have a positive effect in certain diseases [31-33]. For example, in the management of gout, lowering serum UA level has proved a potent treatment target, whereas raising serum UA has been beneficial in multiple sclerosis (MS) $[34,36]$. Although it is uncertain whether MS and Parkinson's disease (PD) patients have gout, a handful (although a negligible percentage) have presented with both conditions. In such presentations, much doubt exists about whether increased serum UA levels in gout could protect against MS/PD or vice versa; however these subjects may have other predisposing confounding factors such as lifestyle patterns, high physical activity levels, infections, asymptomatic metabolic deficits, or diet/herbal medication or alcohol use. The possibility of "risk reversal" exists in subjects with complications of low UA that have been protected from the complications of high UA; however, this hypothesis requires further research. In some studies, altered serum UA level is an independent predictor of mortality in many end-stage diseases in the presence of other comorbid conditions [36-38], and in others, altered serum UA levels might slow the long-term effects of these underlying diseases [34,39].

\subsection{UA Homeostasis in Health and Diseases}

In healthy subjects, the body tightly regulates the production, utilization, and excretion of UA by controlling cell turnover of purine intermediates, filtration, reabsorption, and secretion. Physiologically, plasma UA concentration may be influenced by age, gender, race, and even physical activity [40-43]. It can also vary by as much as $50-120 \mu \mathrm{mol} / \mathrm{l}$ during the day in the same individual due to the effects of diet and exercise [44]. Normally, its excretion depends on plasma levels of urate. The upper limits of normal daily urinary urate excretion are $750 \mathrm{mg}$ for women and $800 \mathrm{mg}$ for men, whereas the lower limit is $250 \mathrm{mg}$ [45-47]. However, excretion varies with body weight and size. Fractional excretion of UA (FE-UA) is estimated to range from $4 \%$ to $14 \%(6-12 \%$ in men and 6-20\% in women) [ 48, 49].

Newborns have UA levels between 2.0 and $6.2 \mathrm{mg} / \mathrm{dL}$, whereas levels in children range from 2.5 to $5.5 \mathrm{mg} / \mathrm{dL}$ [46]. Boys aged 10-18 years have levels of $3.6-5.5 \mathrm{mg} / \mathrm{dL}$, and in girls in this age range, levels fall between 3.6 and $4.0 \mathrm{mg} / \mathrm{dL}$. Compared with girls, boys experience a greater rise during puberty. Adult men ( $>18$ to $<40$ years) normally have UA levels between 2 and $7.5 \mathrm{mg} / \mathrm{dL}$, whereas adult women in the same age range have levels between 2 and $6.5 \mathrm{mg} / \mathrm{dL}$. In men aged $>40$ years, levels range from 2 to $8.5 \mathrm{mg} / \mathrm{dL}$, and in women aged $>40$ years, levels fall between 2 and $8.0 \mathrm{mg} / \mathrm{dL}$. However, due to the uricosuric effects of estrogen (in consonance with progesterone), which is abolished during menopause, values rise steadily in menopausal women compared with those of non-menopausal women [28, 40, 50,51]. Because aging can contribute to low muscle mass, it may also cause a rise in serum UA, supporting the theory that elevated UA may lead to sarcopenia [52].

The intensity and duration of physical activity can also influence serum UA levels. Sutton et al [53] found that plasma UA concentrations in 15 men increased from 6.9 to $8.5 \mathrm{mg} / \mathrm{dL}$ after a $5000-\mathrm{m}$ race and from 6.2 to $7.9 \mathrm{mg} / \mathrm{dL}$ in $11 \mathrm{men}$ after a marathon $(42 \mathrm{~km})$. During a progressive exercise test on a cycle ergometer, the plasma concentration did not change significantly in these 11 subjects. However, plasma oxypurine levels and the urinary excretion of oxypurines increased, and intracellular ATP decreased while adenosine monophosphate (AMP) and adenosine diphosphate increased.

In a parallel study by Green and Fraser [54], the effects of exercise intensity and short-term training on alterations in 
plasma UA level were investigated in two series of subjects aged 19-25 years. The first group of subjects cycled at $120 \%$ maximal oxygen consumption for $1 \mathrm{~min}$ followed by 4 min of recovery until fatigue or until 24 repetitions had been completed; the second cycled continuously at maximal oxygen consumption for $2 \mathrm{~h}$. The results showed a significant post-exercise increase in UA, suggesting that exercise intensity rather than work output is the critical factor mediating increases in blood UA concentration. The results further reaffirmed that UA formation can arise from purine nucleotide degradation and fast-twitch fiber utilization during conditions of high energy utilization. Although exercise can be considered a health management therapy in many cardio-metabolic diseases, some empirical studies have shown an association between intense physical activities; profuse sweating in hot climates, reduced urinary acid excretion, and hyperuricemia[54-56]. Similarly, acute renal failure after exercise at various rates has been reported in studies among patients with familial renal hypouricemia (RHUC) $[47,57,58]$ and may be attributable to exercise-induced oxidative stress among other factors. Because familial RHUC is mostly asymptomatic, serum UA screening should be conducted in affected individuals before any physical training [57] to identify potential risks.

Some studies have tried to establish racial/ethnic background as a socio-demographic factor in susceptibility to the development of abnormal serum UA levels and metabolic syndrome. Studies have been conducted among Hispanics, whites, African-Americans, Asians, and Arabs [59-62], and the results showed, for example, that African-American descent is associated with a greater than $50 \%$ increased risk for gout in both men and women compared with that in whites [61]. De Boer et al [62] found that in a group of non-Hispanic white, non-Hispanic black, and Hispanic adolescents aged 12-19 years, non-Hispanic white males and females had the highest UA levels. Conversely, the prevalence of RHUC is reportedly more frequently in Asian and Arab populations than in populations of other races [47]. These findings are inadequate for drawing inferences because further studies must be performed in additional populations. Increased serum UA or the prevalence of hyperuricemia appears to be associated with the lifestyle choices and economic growth and development resulting from urbanization and westernization [44, 63-65].

Many other factors that regulate UA homeostasis can influence the balance of UA production with the excretion of urate by the kidney and are endogenous or exogenous, genetic, or environmental. Any derangement in this homeostasis is described as either hypouricemia or hyperuricemia.

\subsection{Hypouricemia}

Hypouricemia is arbitrarily defined as a serum urate concentration of $<2 \mathrm{mg} / \mathrm{dL}$. This condition occurs in approximately $2 \%$ of hospitalized patients and $<0.5 \%$ of the non-hospitalized population [66]. Hypouricemia can be a consequence or cause of various physiological or pathological conditions in which there exists an underproduction of urate or increased excretion of urate in opposition to hyperuricemia. It can also result from decreased UA oxidation due to treatment with uricase and decreased renal tubular reabsorption due to inherited or acquired disorders. The possibility that abnormalities in intestinal uricolysis will produce hypouricemia is still under investigation.

Unmistakably, hypouricemia is not a disease condition itself (it is benign) and has been considered a biochemical disorder with no clinical significance other than as a marker of underlying disease $[67,68]$. It is a medical sign that presents due to confounding factors that can be dietary or related to drugs/treatment procedures, genetics, or even physical activity and is often due to an underlying medical condition (Table 1). When analyzed, these factors might give a clear picture of the underlying etiology of hypouricemia. [67, 69, 70].

For example, the coexistence of hypouricemia and hyponatremia often differentiates the syndrome of inadequate secretion of antidiuretic hormone from most causes of hyponatremia [71], whereas hypouricemia and hypouricosuria are considered manifestations of renal tubular damage in primary biliary cirrhosis [72], hypouricemia in the syndrome of inadequate secretion of antidiuretic hormone is primarily the consequence of high UA clearance related to a decrease in tubular UA reabsorption [73].

Chronic consumption of certain foods is associated with serum hypouricemic effects. These foods are categorized as low-purine foods and include kidney and lima beans, coffee, whole-grain bread, asparagus, cauliflower, mushrooms, peas, cereals, and poultry such as chicken, duck, and turkey (see Table 1) $[21,74,75]$.

Additionally, a common long-term effect of mostly vegetarian diets is hypouricemia due to the low purine content of consumed foods [76]. Szeto et al [77] assessed the effects of long-term vegetarian diets and found that they result in mean serum UA value as low as $2.39 \mathrm{mg} / \mathrm{dL}$ Although consuming a vegetarian diet may be very beneficial for hyperuricemic and gout patients, a note of caution is warranted to prevent associated health conditions that may ensue.

Transient hypouricemia can also be a result of total parenteral nutrition (TPN), a health care intervention for patients immobilized by a serious disease condition. Strangely enough, TPN may produce hypouricemia followed shortly by acute gout, a condition normally associated with hyperuricemia[78-80]. The underlying mechanisms for this phenomenon remain unclear and understudied but may include prolonged starvation, interference from other chemical components of TPN, or decreases in UA related to the administration of uricosuric medications [78-80]. Various studies have reported that mutations in proteins responsible for the excretion of urate by the kidneys can lead to defective renal urate handling. Implicated genes include SLC2A9 (solute carrier family 2 [facilitated glucose transporter] member 9), $A B C G 2$ (ATP-binding cassette, sub-family G member 2), SLC17A1 (solute carrier family 17 [organic anion transporter] member 1), SLC22A12 (solute carrier family 22 [organic anion/urate transporter] member 12), GCKR (glucokinase regulatory protein), and SLC16A9 (solute 
carrier family 16 member 9), also known as monocarboxylate transporter 9. For example, SLC22A12 encodes for URAT1, whereas $S L C 2 A 9$ encodes for GLUT9, a member of a family of hexose (fructose and glucose) transport-facilitating proteins. The isoform GLUT9L is expressed on the basolateral membrane of proximal tubules, and the GLUT9S isoform is expressed on the apical membrane of the proximal tubules. Mutation in SLC2A9 can result in defects in the activities of GLUT9, which depends on $S L C 2 A 9$ for regulation. Two kinds of genetic disorders cause hypouricemia: mutations causing xanthine oxidase (XO) deficiency, which reduces UA production, and mutations causing abnormal kidney function, which increases the excretion of UA (reduction in urate reabsorption), collectively known as familial RUHC types 1 and 2 (an autosomal recessive trait). In humans, loss-of-function mutation in URAT1 is reportedly associated with presecretory reabsorption defects and hence the underlying etiology of RHUC type 1 [25, 81, 82, 83]. Conversely, RHUC type 2 is characterized by a reduction in urate reabsorption on both sides of tubular cells and an FE-UA rate higher than $150 \%$ [47]. It is worth emphasizing that hypouricemia with reduced FE-UA is associated with defective UA production, whereas hypouricemia with increased FE-UA is associated with defective proximal tubular transport of UA [84].

Renal hypouricemia can be classified into four [25] or five [83] types based on response to the pharmacological inhibitor pyrazinamide: (1) defective presecretory reabsorption, (2) defective postsecretory reabsorption, (3) enhanced urate secretion, (4) subtotal defect in urate transport, and (5) total inhibition of urate reabsorption. Four mutations in $h U R A T 1$ in subjects with presecretory reabsorption defects (which impair the urate-transporting activity of hURAT1) - G774A, A1155T, and 1639-1643 del-GTCCT-were previously reported [81, $85,86]$, and $\mathrm{T} 1253 \mathrm{G}$ is a newly identified defect. As reported in one patient with idiopathic RHUC whose FE-UA was 95\% compared with $10 \%$ in normal individuals, a homozygous G774A mutation of SLC22A12 resulted in the formation of truncated and inactive hUART1. Because the A1145T and $\mathrm{T} 1253 \mathrm{G}$ mutations were located in the ninth and tenth putative transmembrane domains, these mutations might modulate urate permeability via hUART1 [87]. However, a study by Wakida et al [83] showed that hUARTl might be the gene responsible for presecretory reabsorption defects in RHUC, and a different gene might control post-secretory reabsorption defects owing to an absence of discernible $h U A R T 1$ mutations in subjects with postsecretory reabsorption defects.

Other inborn errors that may decrease UA production are hereditary xanthinuria (a recessive trait) and pure nucleoside phosphorylase deficiency. Mutation of the xanthine dehydrogenase (XDH) gene (located on chromosome 2p22-23) is the underlying cause of xanthinuria, which is either type I or II. Type I results from isolated XDH deficiency, whereas type II results from a dual deficiency in XDH and aldehyde oxidase $[88,89]$. Aside from inborn errors, acquired disorders can also cause defects in UA metabolism.

Complications of RHUC include exercise-induced acute renal failure (EIARF) and urolithiasis, hematuria and nephrolithiasis related to UA, calcium oxalate, or both, in addition to aciduria and hyperoxipurinemia $[47,58]$. Other disease conditions associated with hypouricemia $[21,60,73$, 90-93] are presented in Table 1.

Table 1. Etiology of hypouricemia and some associated diseases

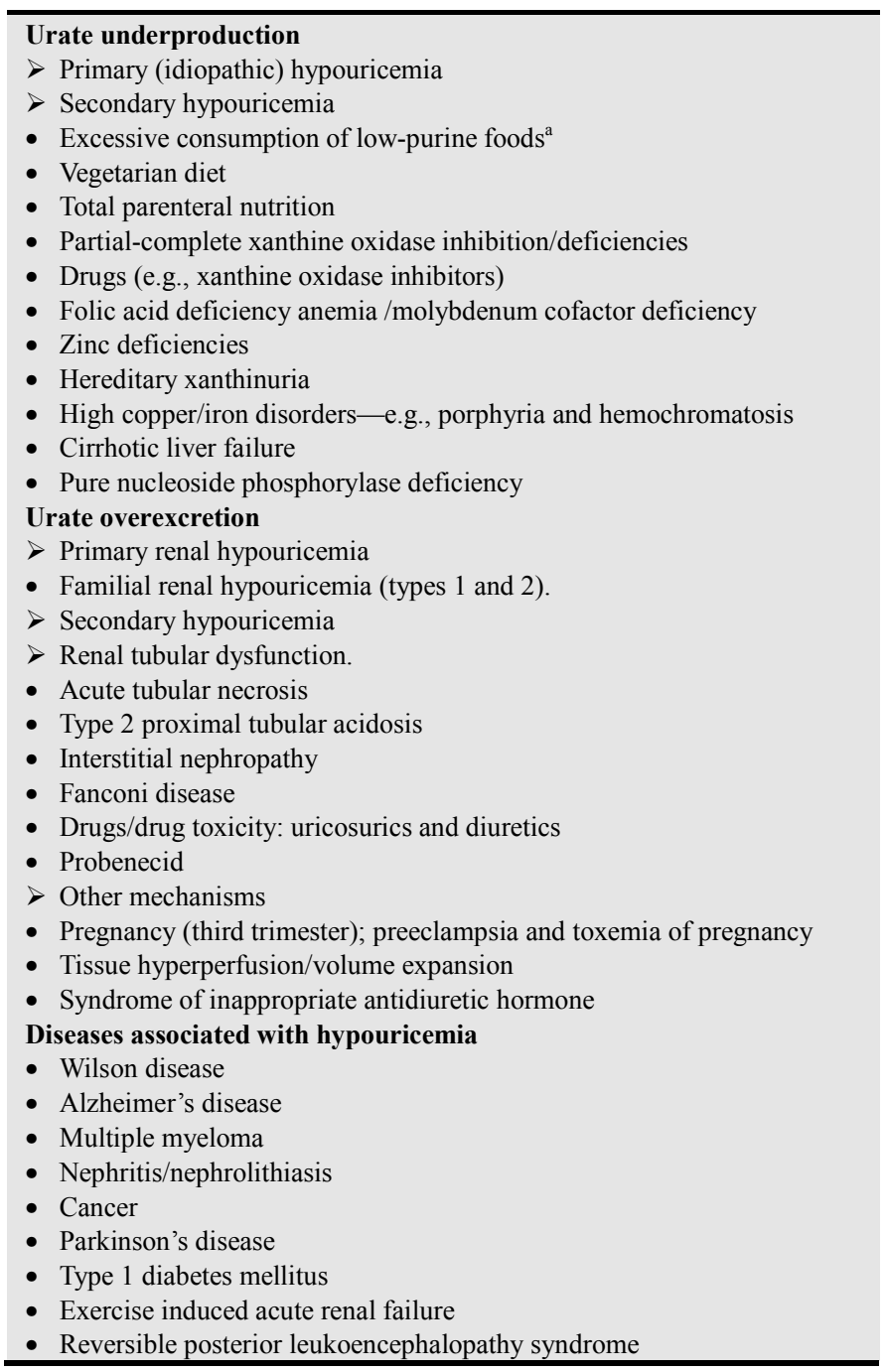

${ }^{a}$ Low-purine foods include whole-grain breads/butter, kidney and lima beans, vinegar, cereals, coffee, cheese, chocolate, cauliflower, poultry (chicken, duck, and turkey), rice, olives, eggs, milk, fruits (especially cherries).

Moderate-purine foods include asparagus, spinach, fish, meat, mushrooms, lentils, and shellfish.

\subsection{Hyperuricemia}

Defined as a blood UA level of $>6 \mathrm{mg} / \mathrm{dL}$ in women and 7.0 $\mathrm{mg} / \mathrm{dL}$ in men [23], hyperuricemia can result from overproduction or decreased excretion of UA or a mixture of both. Hyperuricemia can be transient or asymptomatic; however, chronic hyperuricemia has been implicated in the pathogenesis of many diseases, including cardiovascular disease [94, 95], cancers [24], renal disease [96, 97], type 2 diabetes mellitus [98], and chronic nonspecific musculoskeletal pain [99].

Many factors, both modifiable and unmodifiable have been 
implicated in the etiology of hyperuricemia, and they can be dietary, genetic, or acquired. As discussed previously, UA is a product of purine metabolism, and therefore, excessive and prolonged consumption of high-purine foods is associated with increased serum UA levels [100-102]. However, a purine-rich diet is a common but minor cause of hyperuricemia, because if the renal UA handling system is efficient, UA accumulation will not raise concerns. Moreover, considering the variation in the purine content of foods, diet alone is insufficient to cause hyperuricemia but instead can exacerbate its complications [100].

The sweetening industry has begun using additives such as high-fructose corn syrup, table sugar, and honey, all of which are rich in fructose. Today, most sweetened processed foods such as pastries are laden with high-fructose corn syrup [103]. Fructose has high purine content and when consumed in significant amounts in western diets, it is implicated in the pathogenesis of metabolic syndrome [104] and hyperuricemia. [105]. Unlike other sugars, fructose causes a rapid rise in serum UA levels. In fact, daily consumption of more than four brands of fructose-sweetened soft drinks imparted an odds ratio of 1.82 for hyperuricemia in a US population [106].

Increased fructose intake has been hypothesized to raise serum UA levels by increasing ATP degradation to AMP and activating the pathway of purine degradation to urate $[107,108]$, a cascade of processes that begins with fructose phosphorylation [109]. Other mechanisms may also include the production of reactive oxygen species, activation of cellular stress pathways, and increase in UA synthesis [110]. Furthermore, fructose reportedly inhibits UA excretion, apparently by competing with the access of UA to the transport protein SLC2A9 [111]. Aside from fructose, substrates such as sorbitol, sucrose, lactate, and methylxanthines [112] increase serum urate concentration.

It remains rather controversial whether high-fructose sweeteners cause hyperuricemia or increase the risk and complications of hyperuricemia. Intervention studies such as those of Johnson et al [113], MacDonald [114], Emerson [115], and Fox [116] found that the consumption of fructose experimentally induces an acute rise in serum UA concentration. Conversely, Crapo [117], Huttenen [118], Curari [119], Osei [120], Anderson [121], Koh et al [122], and Grigoresco et al [123] observed no influence of fructose on serum UA concentration.

Most intriguing, Sun et al [124] found that increased dietary fructose intake was not associated with increased risk of hyperuricemia, whereas increased dietary alcohol intake was significantly associated with an increased risk, and increased fiber intake was significantly associated with decreased risk. These findings are consistent with those of other intervention studies that found associations between alcohol consumption and increased serum UA levels [101, 125].

Beer, spirits, wine, and liqueur influence UA concentration. In fact, beer intake is an independent factor for serum UA increase [126] due both to its alcohol content and its high-quality purines [127]. Beer intake increases UA more effectively than liqueur, but moderate wine intake does not increase UA [102,127]. As a by-product of fermentation, beer has a high purine content that is predominately present as readily absorbable guanosine, and its intake enhance urate production, compounding the stimulatory effect of alcohol metabolites on renal urate reabsorption [128]. Ethanol increase urate synthesis by enhancing the turnover of adenine nucleotides [129]. Acutely, excess consumption of alcohol may cause temporary lactic acidemia (lactic acidosis), reduced renal urate excretion, and induced hyperuricemia. Chronic alcohol intake stimulates purine production by accelerating the degradation of ATP to AMP via the conversion of acetate to acetyl-coenzyme A in the metabolism of alcohol [130]. Hence, alcohol intake increases UA concentration by reducing excretion [131,132] and increasing urate production [129]. Additionally, ethanol decreases the excretion of UA by promoting dehydration and (rarely) clinical ketoacidosis [128].

Table 2. Etiology of hyperuricemia and some associated diseases

\begin{tabular}{|c|}
\hline 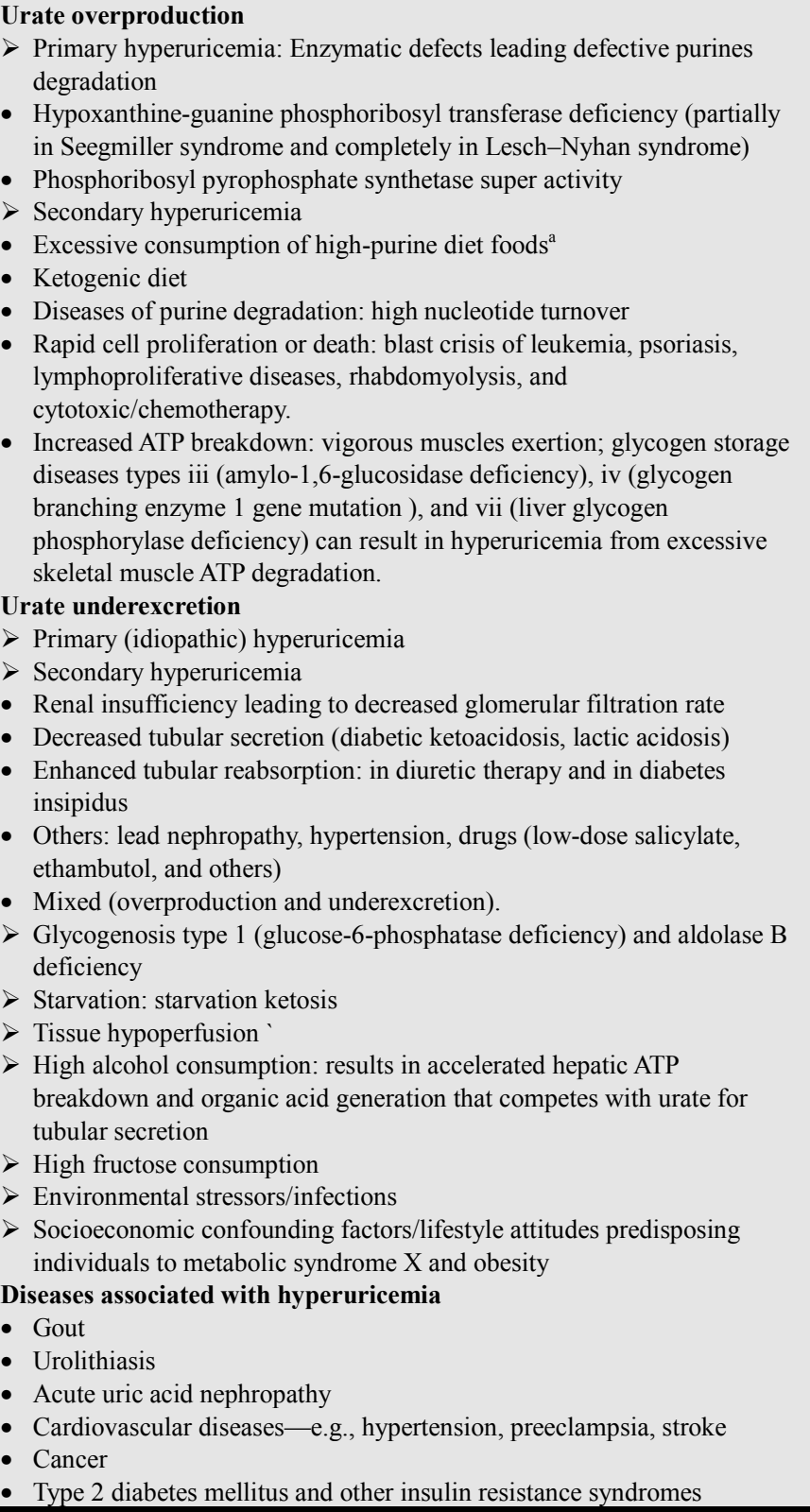 \\
\hline
\end{tabular}


${ }^{a}$ High-purine foods include anchovies, consommé, legumes, meat extracts, organ meats (kidneys, liver, and brains), roe (fish eggs), sardines, tofu, mincemeat, and yeast.

The consumption of foods with diuretic properties has been associated with the incidence of mild asymptomatic hyperuricemia. These foods (mostly herbs and fruit juice) have inhibitory effects on renal UA excretion and include eggplant, garlic, cucumbers, cranberry, lemon, and asparagus, among others [133].

Starvation and fasting, which are modifiable factors, have been associated with the etiology of hyperuricemia, presumably due to the effect of ketones on UA excretion. This phenomenon can be observed among prolonged fasters, particularly during Ramadan [11,134]. Other modifiable and un-modifiable factors associated with hyperuricemia are presented in Table 2 .

\section{Serum UA as an Antioxidant and Pro-Oxidant}

In humans, more than half of the antioxidant capacity of the plasma comes from serum UA. More specifically, UA represents approximately $60 \%$ of the total human serum antioxidant status [135]. As a direct-acting, low-molecular-weight antioxidant, UA controls the rate and activities of free radicals, especially reactive oxygen and nitrogen species (singlet oxygen, peroxyl, and hydroxyl radicals) whose activities that predispose cells and tissues to oxidative stress and damage. Under certain conditions, UA in the cell milieu also gives off an electron as an antioxidant to become a urate radical that can be regenerated to UA by ascorbate. Conversely, as a strong reducing agent similar to ascorbic acid, UA (urate radical) can act as a pro-oxidant under many conditions (especially during periods of lower ascorbate availability). Hence, as a pro-oxidant, UA causes disease, but as an important antioxidant, ameliorates disease conditions $[136,137]$. Thus UA can act as a friend or a foe depending on the preexisting cellular environment and its oxidative state.

During purine metabolism, the activities of the enzymes xanthine oxidase and xanthine dehydrogenase produce UA, superoxide, and reduced nicotinamide adenine dinucleotide [138]. Superoxides in turn react with nitric oxide to form peroxynitrite, an oxidant. However, UA in turn scavenges peroxynitrite, preventing peroxynitrite-induced tyrosine nitration [139]. Conversely, superoxide peroxidase catalyzes the degradation of superoxide to hydrogen peroxide. If levels of superoxide dismutase are low, nitric oxide reacts with superoxide to form peroxynitrite, which can initiate a cascade of lipid peroxidation reactions. Furthermore, the urate radical (due to increased UA levels) acts as a pro-oxidant under conditions of low ascorbate, causing direct vascular oxidative damage [140].

Although the body is constantly bombarded with the adverse effects of reactive species generations due to many exogenous risk factors such as lifestyle choices and environmental effects (e.g., smoking, alcohol consumption, physical stress), it tends to control the rate of production of free radicals tightly and hence this production does not outwit the rate of UA utilization/elimination. Therefore, if for any reason these defense systems are compromised, pathological conditions manifest due to oxidative stress. Under this condition of oxidative stress, the "protectors" now becomes the "villains," starting a cascade of cellular responses. In diseases such as gout and MS, abnormal levels of UA below and above reference range constitute a primary loss of protection against oxidative stress [102,141]. This loss of protection from oxidative/nitrosative stress one by one exposes the body to chronic adverse health conditions that could be asymptomatic or symptomatic and set the stage for full-blown disease, especially in the presence of other predisposing comorbidities. Such diseases have a potent mechanism through which abnormal serum UA contributes to initiation or progression, although high or low serum UA levels have both risk-predisposing effects as well as biological functions (protection) in conditions such as PD, Alzheimer's disease, stroke, renal disease, gout, and MS.

\section{Systemic Consequence of Abnormal Serum UA Levels: The Doubled-Edged Sword}

High and low serum UA levels have significant systemic effects. These effects can be explained based on the following assumptions. (1) Exceeding the body's threshold of renal handling of UA results in the oversaturation of its UA carrying capacity, causing systemic overload (a product of defective production and elimination). Armed with the potential to be reactive (especially during prolonged intracellular oxidative challenges), soluble UA exerts negative or positive effects on plasma antioxidant capacity. Depletion of this capacity (owing to the increased circulation of reactive UA, oxygen, and nitrogen species at levels the body cannot handle) opens the door to many metabolic complications that may be occurring in the body but have remained asymptomatic. It is notable that chronic episodes of elevated serum UA are implicated in many defective metabolism-induced complications. (2) On the contrary, owing to the defective production and elimination of UA, low levels of UA may have detrimental effects, especially in neural tissues. Reduced UA along with possible reductions in the levels of supportive antioxidants such as ascorbic acid, compromises antioxidant capacity, leads to a cascade of defects resulting from reoccurring exposure of the body to reactive species and poorly handled oxidative stress.

Viewed from both edges, as a cellular defensive weapon, UA can be an antioxidant or a pro-oxidant depending on the pre-existing cellular environment and demand. In plasma, its antioxidant activities are more pronounced and tend to prevent cellular membrane damage from reactive species-induced oxidative stress and facilitate cell integration and regeneration. Its activities on the cell membrane promote cellular health by scavenging peroxynitrite, superoxide, and hydroxyl ions. 
Once UA enters the cell, it can act as a pro-oxidant by losing its antioxidant status due to electron donation to form urate radicals or by stimulating nicotinamide adenine dinucleotide phosphate oxidase [142] and it can induce oxidative stress, stimulate inflammatory mediators, cause endothelial dysfunction, and activate the local renin-angiotensin system. $[142,143]$. As a double-edged sword, abnormal serum UA levels - both below and above the reference range - confers an increased risk of adverse health effects, as shown in Figs. 2-4.

Abnormally high levels of UA can predispose individuals to or even complicate cardiovascular disease, hypertension, atherosclerosis, hyperinsulinemia, cancers, renal insufficiency, diabetes mellitus, and cerebrovascular events, whereas abnormally low levels of UA can translate to greater oxidative stress and the possibility of developing complications associated with this increased stress. There is evidence for an association between hypouricemia and optic neuritis [144], MS [141], PD [145], and cancers of the upper stomach [15]. Recent evidence has linked hypouricemia with oxidative stress in type 1 diabetes mellitus and EIARF $[58,92]$. The link between renal hypouricemia (idiopathic or hereditary) and acute renal failure is postulated to occur via the oxidative stress pathway induced by exercise and UA precipitation. Evidently, FE-UA in hypouricemia is increased $(>150 \%)$, leading to hyperuricosuria. In a patient studied by Jennin et al [47], FE-UA changed from $200 \%$ to $732 \%$ between two hospital admissions, with a daily urinary UA excretion of 411 mg. The severe clinical manifestations - low UA and very high FE-UA - that characterized both admissions suggested RHUC.

Although the pathogenesis of EIARF is unclear, three hypotheses have been developed to explain the condition: (1) Acute urate nephropathy due to increased production of UA during physical exercise. (2) Ischemic kidney injury secondary to exercise-induced oxidative stress in the absence of the protective effect of the antioxidant UA [146-149]. (3) Because URAT1 is an anion/urate exchanger, inactivation of URAT1 via loss-of-function mutations in either URAT1 or GLUT9 will not only abolish UA absorption but also block the secretion of organic anions to the tubular lumen. The tubular accumulation of toxic urate coupled with the organic anions produced during exercise (such as lactate) may have detrimental effects on renal proximal tubules, leading to acute tubular injury [150]. Most interesting, acute renal failure is evident as a complication in both abnormally high [33] and low. $[47,150]$. UA levels associated with significant morbidity. This gives credence to the doubled edged sword effects of abnormal uric acid.

Table 3. A review of possible mechanisms by which abnormal serum UA causes diseases

\section{HYPERURICEMIA}

$>$ Acute renal failure via

- Renal vasoconstriction (via inhibition of nitric oxide synthase 1), reduction in endothelial cell nitric oxide (via NADPH oxidase in adipocytes and endothelial cells) and stimulation of renin-angiotensin system,

- Anti-angiogenic properties (inhibition of endothelial cell apoptosis, which accelerates endothelial cell loss and retards recovery,

- Pro-oxidant properties (stimulation of oxidants [via increasing activities of NADPH oxidase] and peroxynitrite-associated radicals [allantoin, 6-aminouracil, and triuret]),

- Proinflammatory properties (stimulation of monocyte chemoattractant protein-1; C-reactive protein activation of nuclear factor $\kappa \mathrm{B}$ and $\mathrm{p} 38$ mitogen-activated protein kinase),

- Alteration of renal autoregulation via development of preglomerular arteriolar disease (linked with systemic glomerular hypertension and cyclooxygenase-2-mediated, thromboxane-induced diseases) [33,142,162-164]

$>$ High serum UA in type 2 diabetes mellitus acts via

- Insulin resistance syndrome associated with hyperinsulinemia,

- Impaired glucose tolerance and early onset of overt (diabetic) nephropathy $[98,108,165,166]$.

$>$ High serum UA in type 1 diabetes mellitus is linked to overproduction of nitric oxide and oxidative stress [92].

$>$ High serum UA can exacerbate chronic kidney disease via endothelial dysfunction, activation of local angiotensin system, increase oxidative stress, proinflammation and proliferation [167,168].

$>$ High serum UA is associated with high rates of severe acute respiratory syndrome and COPD, especially among current smokers, linked to inflammatory defects.

- Abnormally high serum UA is associated with acute exacerbation of COPD [169-171].

$>$ Increased serum UA is associated with anovulatory cycles linked to follicular development or an underlying endocrine or metabolic disturbance [28].

$>$ High UA induces gout via

- Syk and P13K activation, phagocytosis and cytokine production,

- Activation of Toll-like membrane receptors,

- MSU crystal-induced inflammation associated with NALP3 inflammasome activation and IL-1 $\beta$ release [172-174].

$>$ High UA is also associated with chronic nonspecific musculoskeletal pain, possibly via

- MSU-induced inflammation,

- Production of prostaglandin and bradykinin and sensitization of nociceptors,

- Release of substance P resulting in vasodilation, plasma extravasations, leucocytes recruitment, mast cell degranulation, and release of prostaglandins and cytokines [172-174].

$>$ High serum UA levels may contribute to neurodegenerative disease through activation of the NLRP3 inflammasome via the MSU crystal-NLRP3 inflammasome-IL-1 $\beta$ pathway [1,175-177].

$>$ Cardio-renal-metabolic diseases are exacerbated in the presence of high serum UA due to its role in

- Endothelial dysfunction and vascular smooth muscle cell proliferation (via activation of platelet-derived growth factor and mitogen-activated protein kinase) and pre-glomerular arteriopathy,

- Increased oxidative redox stress,

- Fatty acid synthesis and production of NADPH, 
- Stimulation of renin-angiotensin system: juxtaglomerular renin production and a decrease in macula densa nitric oxide synthetase expression,

- Hyperinsulinemia and insulin resistance,

- Accelerated atherosclerosis and renal vascular resistance due to vasoconstriction,

- Salt sensitivity and increased sodium reabsorption,

- Leptin interaction $[44,162,178-181,183]$.

$>$ High serum UA induces tumor growth and metastasis in cancer cells via

- Activation of NADPH oxidase and generation of ROS in tumor-associated leukocytes and adipocytes leading to proinflammatory stress,

- Downregulation of XOR expression and adiponectin,

- Loss of XOR in most aggressive cancer cells contributing to tumor cell proliferation, migration and survival and progression from early stage to highly aggressive cancer.

- Leptin-related downregulation of cancer cell XOR [24].

$>$ The frequent occurrence of hyperuricemia in HIV-infected patients may result from multiple metabolic, immunologic, and pathologic abnormalities characterizing the progression of HIV disease from asymptomatic infection to terminal illness.

- Hyperuricemia complicates the course of HIV disease via

- Prolonged fever due to infection, neoplastic and autoimmune disorders,

- Hypercatabolic state associated with fasting or cachexia,

- Viremia,

- Possible HIV-related loss of mononuclear cells [184].

HYPOURICEMIA

$>$ induces Exercise induced acute renal failure via

- Acute urate nephropathy due to increase production of UA during physical exercise,

- Ischemic kidney injury secondary to exercise-induced oxidative stress potentiated by NADPH oxidase stimulation

- Accumulation of toxic urate coupled with organic anions (e.g., lactate) produced during exercise leading to acute renal proximal tubular injury. $[47,146,148,150]$.

$>$ Low serum UA in type 2 diabetes mellitus is associated with

- Worse metabolic control,

- Hyperfiltration and late onset of progression to overt (diabetic) nephropathy [182].

$>$ Low serum UA contributes to neurodegenerative disease initiation and progression via

- Reduction of antioxidant capacity,

- Induction of oxidative and nitrosative stress and inflammation, which leads to neuronal degeneration and lower survival.[1,175-177]

$>$ Low physiological levels of serum UA stimulate mammary cell aggressiveness in vitro [24].

Summary: Low serum UA levels in disease entities are most closely associated with high mortality rate, whereas high serum UA levels are associated with high morbidity rate.

[COPD, chronic obstructive pulmonary disease; HIV, human immunodeficiency virus; IL, interleukin; MSU, monosodium urate; NADPH, nicotinamide adenine dinucleotide phosphate; NLRP3,NOD-like receptor family- pyrin domain containing 3; XOR, xanthine oxidoreductase]

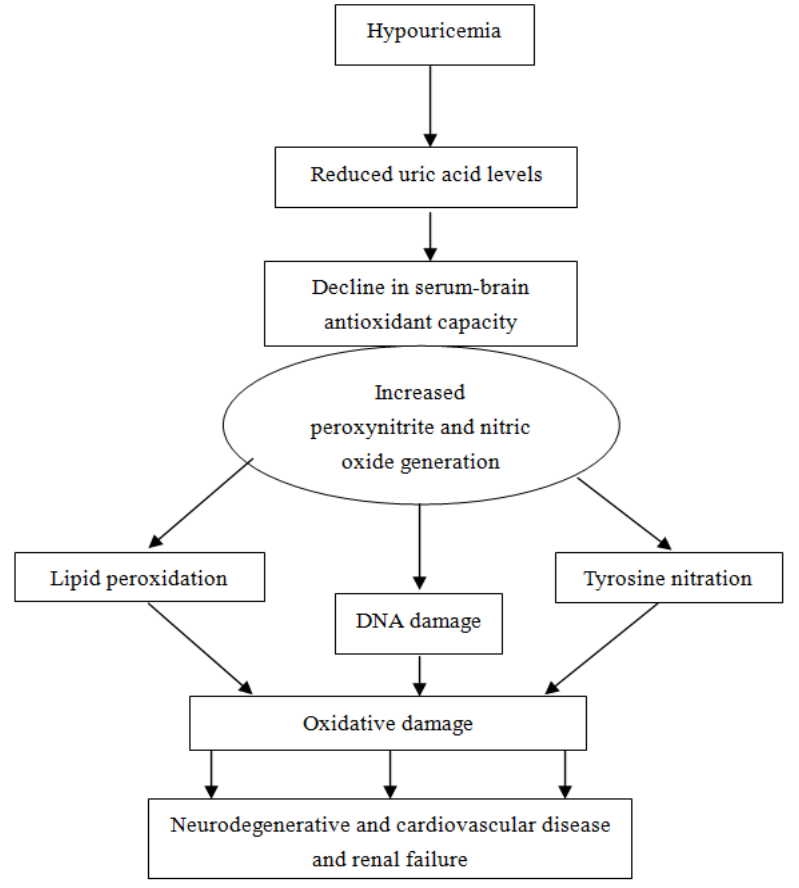

Figure 2. Cascade of defects associated with hypouricemia: Low levels of serum uric acid (UA) can reduce serum and brain antioxidant capacity. Increased oxidative and nitrosative stress resulting from increased generation of nitric oxide and peroxynitrite causes lipid peroxidation, DNA damage, and tyrosine nitration, ultimately leading to a cascade of defects including neurodegenerative and cerebrovascular diseases and renal failure.

\section{Where Have We Gone Wrong and what Can be Done}

Available evidence suggests that man's problems started about 10-20million years ago, when for some reasons, two independent mutations in the uricase gene occurred, impeding the conversion of urate into a more soluble allatoin like in lower animals [151]. The resultant effect is the higher circulatory serum urate level, a situation that predisposes man to increase susceptibility to hyperuricemia and associated complications. The situation became worst when modern humans adopted "risky" health practices in a bid to modify their lifestyles and improve their environment. Consider, for example, our food and water sources. Due to human activities and industrialization during the past 100 years, the $\mathrm{pH}$ of the soil has shifted toward acidity. Acidic soils below pH 6 may have reduced calcium and magnesium, and soil with a $\mathrm{pH}$ of $>7$ can have chemically unavailable iron, manganese, copper, and zinc. The addition of dolomite and manure (e.g., animal dung) raises the $\mathrm{pH}$ in soil with $\mathrm{pH}$ values of $<6$ [152]. Since the agricultural revolution, the recurring dietary trend is characterized by decreased potassium compared with sodium and an increase in chloride compared with bicarbonate, thereby reversing the $\mathrm{K}^{+} / \mathrm{Na}^{+}$ratio $[153,154]$.

Consequently, modern humans have a diet poor in 
magnesium, potassium, and fiber and rich in saturated fat, simple sugars, sodium, and chloride compared with that consumed during the pre-agricultural era [154]. This diet might progressively induce metabolic acidosis. With advancing age, renal acid-base regulatory function gradually declines, resulting in an increase in diet-induced metabolic acidosis attributable to the modern diet [155]. A low-carbohydrate, high-protein diet, with its increased acid load, may in fact cause only a slight change in blood chemistry but result in rather significant changes in urinary chemistry, which in turn has negative influences on blood chemistry.

Thus, urinary magnesium, citrate, and $\mathrm{pH}$ are decreased; urinary calcium, un-disassociated UA, and phosphate are increased [152]. The alkalinization of urine via an alkaline diet has remained a proposed mechanism for managing musculoskeletal, cardiorenal, and metabolic diseases and accumulated UA loads $[76,156]$, although its potency remains disputed. Various studies have recommended a balanced vegetarian diet with moderate animal protein (meat and fish) and purine content, adequate fluid intake, high alkali loads from fruits, vegetables, and fiber, and moderate alcohol consumption as an improvement over the westernized diet composed of more acid-prone foods such as high animal protein, saturated fats, simple sugars, and alcohol $[76,152,156]$.

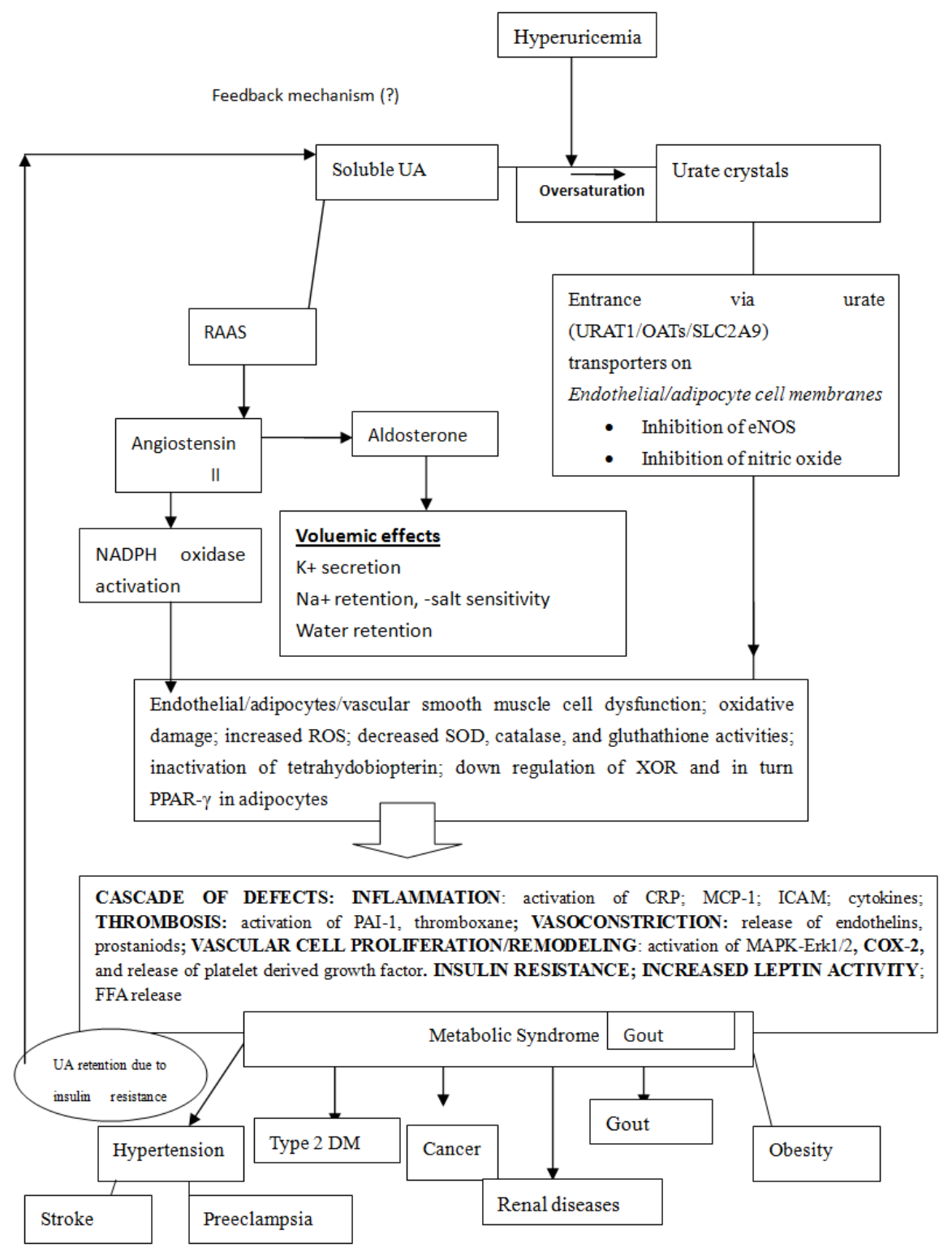

Figure 3. Cascade of defects associated with hyperuricemia: In hyperuricemia, a high concentration of uric acid circulates in the serum. In conditions of oversaturation due to altered systemic pH, soluble uric acid has the potential to crystallize as monosodium urate in soft tissues or enter target cells and directly or indirectly lead to a cascade of systemic defects including endothelial dysfunction, activation of the local renin-angiotensin system, oxidative stress increase, proinflammation, and proliferation. [COX-2, cyclooxygenase-2; CRP, C-reactive protein; eNOS, endothelial nitric oxide synthetase; FFA, free fatty acid; ICAM, intercellular adhesion molecule-1; MAPK-Erk1/2, mitogen-activated protein kinase-extracellular signal-regulated kinase 1/2; MCP-1, monocyte chemo attractant protein-1; OAT, organic anion transporter; PAI-1, plasminogen activator inhibitor-1; PPAR- $\gamma$, peroxisome proliferator-activated receptor-gamma; $R A A S$, renin-angiotensin-aldosterone system; ROS, reactive oxygen species; SLC2A9, solute carrier family 2 [facilitated glucose transporter] member 9; SOD, superoxide dismutase; URAT, uric acid transporter; XOR, xanthine oxidoreductase]. 


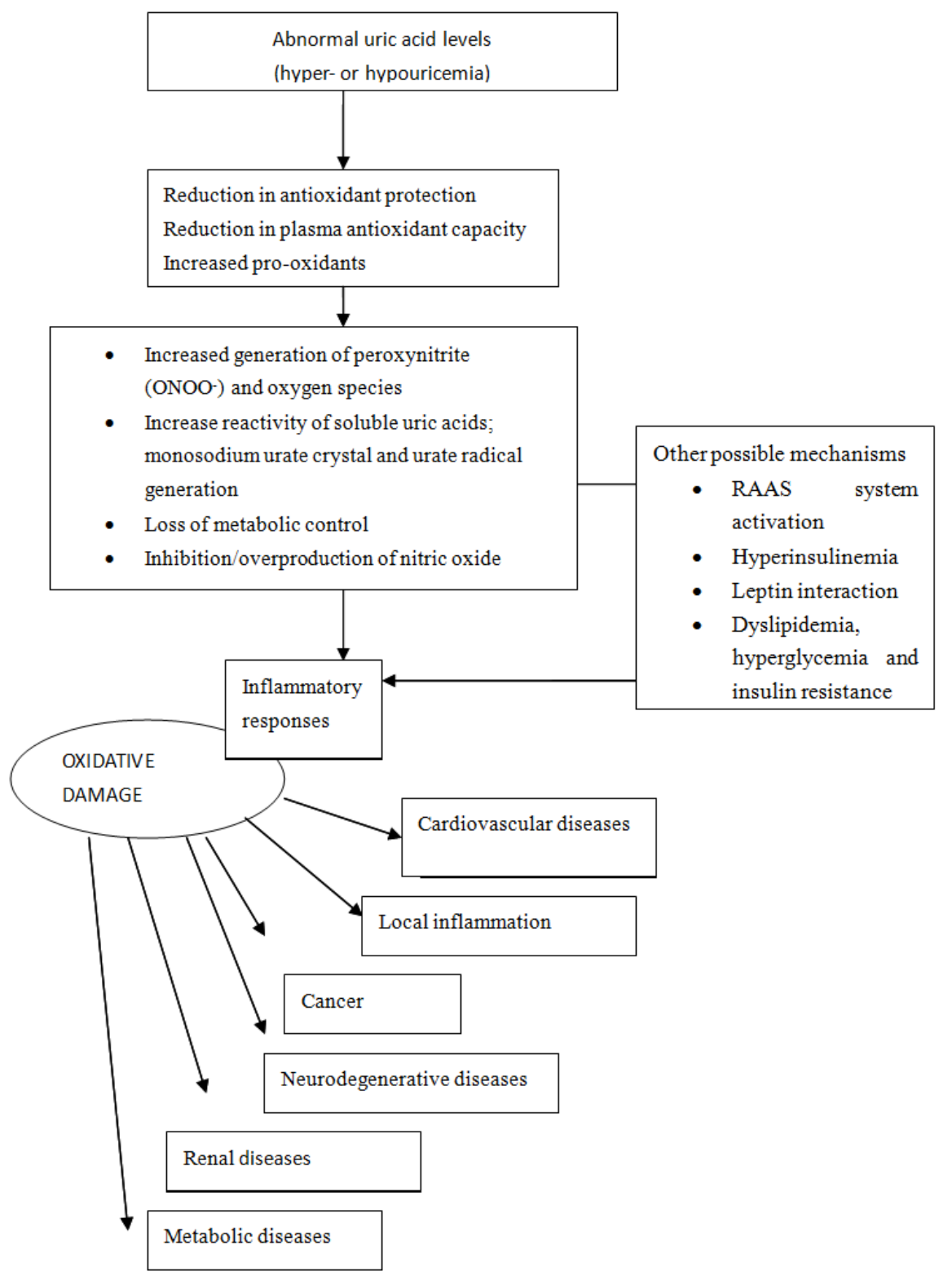

Figure 4. Proposed mechanism through which abnormal serum uric acid could induce and affect the progression of various disease entities. [RAAS, renin-angiotensin-aldosterone system].

However, diet may be a confounding factor in the etiology of deranged serum UA levels. Empirically, diet can influence the occurrence of high UA concentrations in that a positive association is observed with high intakes of meat (particularly red meat), fructose, and seafood, and a negative association with the dairy products, coffee, and caffeinated drink intake $[102,105,126,157,158]$. Although the consumption of protein, meat, and legumes, which are associated with high purine intake, was unrelated to serum UA concentration in a study by de Oliveira et al [157] because a purine-rich diet was responsible for only $1-2 \mathrm{mg} / \mathrm{dL}$ of serum UA $[22,159]$, it is reasonable to suggest that dietary factors associated with metabolic syndrome could indirectly influence urate concentration [158]. Hence, it is worthwhile to advocate healthy eating as an effective and inexpensive way to manage abnormal UA levels. Chronic consumption of diets that increase the odds for derangement in serum UA levels should be discouraged. With advancing age, individuals should check their dietary patterns and avoid overindulgence in risky eating habits and lifestyle choices that predispose them to metabolic deficits. Regular screening of serum UA levels should be conducted. For individuals battling abnormal UA levels (high or low), moderate to regular physical activity and maintaining normouricemia is recommended. Campaigns to raise awareness about the dangers associated with deranged UA levels should be undertaken, especially in developing countries. Clearly, the triad of deranged UA, insulin resistance, and abdominal adiposity are integral to the etiology of many non-communicable diseases in developed and developing countries. In most developing societies, much research on local foods remains to be performed to ascertain whether they promote metabolic deficits.

In addition to the drawbacks introduced by our food sources are those related to water sources. Although it may seem 
negligible, water content might have a role in the body's homeostasis. The water consumed by modern humans has been modified and re-modified for absolute cleanliness using various procedures (such as reverse osmosis, alkaline ionization, and distillation). Disputable though it may seem, these processes may have silent adverse effects on the body. These choices are again where we have gone wrong. Human activities have resulted in an increasing incidence of water toxification and pollution such as lead poisoning, which may contribute to the observable increased disease burden. Lead-induced nephropathy is among the factors associated with high serum UA levels (see Table 2). All of the evidence points to derangement in body chemistry, exposure of the body to additional stress through reduced antioxidant status of plasma in which serum UA plays a central role, and lowered resistance to invading disease entities. Abnormal UA (high or low) is a risk factor for morbidity and mortality in certain disease entities [160]. For example, diabetic patients with low serum UA levels associated with hypoalbuminemia have a higher risk of death, likely due to the deadly short-term effects of oxidative stress characterized by hypoalbuminemia, loss of antioxidant effect of low serum UA levels, or both [160]. It could be concluded therefore that as a double-edged sword, abnormal serum UA among other players in any disease entity exacerbates disease conditions because of the increased exposure to oxidative stress (which initiates disease status) and the lowered antioxidant capacity of the plasma (advances disease course); hence, it cuts with both edges (Table 3). UA levels should be considered seriously because (1) subjects with derangement in UA levels are frequently asymptomatic, and (2) the effects of any derangement, although slow at onset, can rapidly progress and become widespread.

\section{Conclusion}

Consistent data demonstrate that altered serum UA level both markedly below and above the reference range for individual traits and contexts is associated with adverse health effects, a situation referred to as a doubled-edged sword. Specific prevention plans for susceptible individuals should include UA status monitoring and education about derangement management procedures. Regular routine screenings for individuals susceptible to abnormal UA are highly recommended. These individuals include patients with renal impairment, chronic nonspecific musculoskeletal pain, and compromised respiratory, immune, and hemodynamic states; smokers, pregnant women, and patients with medical conditions associated with hyperuricemia (gout, urolithiasis, type 2 diabetes mellitus, stroke, preeclampsia) or hypouricemia (Fanconi syndrome; Wilson disease; folic acid, molybdenum cofactor, and zinc deficiencies; high copper and iron disorders). Individuals with dietary patterns associated with the risk of developing hypouricemia (vegetarian, TPN) or hyperuricemia (high alcohol and seafood consumption, high-fructose syrup consumption) and men and women aged $>40$ years who may be susceptible to cardiovascular diseases such as hypertension, metabolic syndrome, and diabetes mellitus should be checked routinely for derangement in serum UA levels. Among athletes, routine screening of UA levels as a prerequisite for athletic participation, especially in schools, should be encouraged to prevent complications associated with EIARF among asymptomatic individuals with abnormally low UA levels. Any derangement from normouricemic status can exacerbate a reduction in plasma antioxidant capacity, and the resulting increased oxidative stress potentiates the progression of any existing disease entity, be it neurodegenerative, renal, cardiovascular, metabolic, or cerebrovascular.

\section{Acknowledgements}

The authors are grateful to Miss Nyebuk Daniel for her role in the proofreading and typesetting of the manuscript.

\section{References}

[1] Fang P, Li X, Luo JJ, Wang H, Yang XF. A double- edged sword: uric acid and neurological disorders. Brain Disorders \& Therapy 2013; 2(2):109. doi: 10.4172/2168-975X. 1000109.

[2] Nan H, Qiao Q, Dong Y, Gao W, Tang B, Qian R, et al. The prevalence of hyperuricemia in a population of the coastal city of Qingdao, china. The Journal of Rheumatology 2006;33(7): $1346-1350$

[3] Arromdee E, Michet CJ, Crowson CS, O'Fallon WM, Gabriel SE. Epidemiology of gout: is the incidence rising? The Journal of Rheumatology 2002; 29:2403-2406.

[4] Johnson RJ, Perez-Pozo SE, Sautin YY, Manitus J, Sanchez-Lozada LG, Feig DI, et al. Hypothesis: could excessive fructose intake and UA cause type 2 diabetes? Endocrinology Reviews 2009;30(1): 96-116

[5] Takayama S, Kawamoto R, Kusunoki T, Abe M, Onji M. Uric acid is an independent risk factor for carotid atherosclerosis in a Japanese elderly population without metabolic syndrome. Cardiovascular Diabetology 2012; 11:2. doi: 10.1186/1475-2840-11-2.

[6] Gagliardi AC, Miname MH, Santos RD. Uric acid: a marker of increased cardiovascular risk. Atherosclerosis 2009;202:11-17

[7] Kanellis J, Kang DH. Uric acid as a mediator of endothelial dysfunction, inflammation and vascular disease. Seminars in Nephrology 2005; 25:39-42.

[8] Bonventure JV, Zuk A. Ischemic acute renal failure: an inflammatory disease? Kidney International 2004; 66(2):480-5

[9] Barr WG. Chapter 135: Uric acid. In: Walker HK, Hall HD, Hurst JW, editors. Clinical methods: the History, Physical and Laboratory Examinations, $3^{\text {rd }}$ edition. Boston: Butterworth; 1990.

[10] Desideri G, Castald G, Lombardai A, Mussap M, Testa A, Pontremoli R, Punzi 1, et al. Is it time to revise the normal range of serum uric acid levels? European Review for Medical and Pharmacological Sciences 2014; 18:1295-1306.

[11] Ganong WF. Review of medical physiology. 22nd ed. Mc Graw Hill Professionals; 2005. 
[12] Anzai N, Ichida K, Jutabha P, Kimura T, Babu E, Jin CJ, et al. Plasma urate levels is directly regulated by a voltage driven urate efflux transporter URATv1(SLC2A9) in humans. Journal of Biological Chemistry 2008; 283:26834-8.

[13] Hosomi A, Nakanishi T, Fujita T, Tamal I. Extrarenal elimination of uric acid via intestinal efflux transporter BLRP/ABCG2. PLoS One 2012; 7(2):e30456.

[14] Peden DB, Hohman R, Brown ME, Mason RT, Berkebile C, Fales HM, et al. Uric acid is a major antioxidant in human nasal airway secretions. Proceedings of National Academy of Science USA 1990; 87:7638-42

[15] Pietraforte D, Castelli M, Metere A, Scorza G, Samoggia P, Menditto A, et al. Salivary uric acid at the acidic $\mathrm{pH}$ of the stomach is a principal defense against nitrites- derived reactive species: sparing effects of chlorogenic acid and serum albumin. Free Radicals Biology \& Medicine 2006; 41: 1753-63.

[16] Hara K, Lijima K, Elias MK, Seno S, Tojima I, Kobayashi T, et al. Airway uric acid is a sensor of inhaled protease allergens and initiates types 2 immune responses in respiratory mucosa. Journal of Immunology 2014; 192(9):4032-42.

[17] Mount DB, Kwon CY, Ziandi-Nejad K. Renal urate transport. Rheumatic Disease Clinics of North America 2006; $32: 313-331$

[18] Sperling O. Hereditary renal hyperuricemia. In: Scriver CD, Beaudet AL, Sly WS, Valle D, editors. The metabolism and molecular basis of inherited diseases, New York: Mc Graw Hill; 2001, p. 5069-84.

[19] Steele TH. Hyperuricemic nephropathies. Nephron, 1999; 81:(suppl 1):45-9.

[20] Hediger MA, Johnson RJ, Miyazaki H, Endou H. Molecular physiology of urate transport. Physiology (Bethsaida) 2005; 20:125-133.

[21] Kutzing MA, Firestein BL. Altered uric acid levels and disease states. The Journal of Pharmacology and Experimental Therapeutics 2008;324(1):1-1

[22] Emmerson BT. The management of gout. The New England Journal of Medicine 1996; 334:445-51.

[23] Obermayr RP, Temml C, Gutjahr G, Knechtelsdorfer M, Oberbauer R, Klauser- braun R. Elevated uric acid increases the risk for kidney disease. Journal of American Society of Nephrology 2008; 19:2407-2413.

[24] Fini MA, Ellias A, Johnson RJ, Wright RM. Contribution of uric acid to cancer risk, recurrence, and mortality. Clinical and Translational Medicine 2012, 1:16. doi: 10.1186/2001-1326-1-16.

[25] Hisatome I, Tsuboi M, Shigemesa C. Renal hypouricemia. Nihon Rinsho 1996; 54(12):3337-42.

[26] Klemp P, Stansfield SA, Castle B, Robertson MC. Gout is on the increase in New Zealand. Annals of Rheumatic Diseases $1997 ; 56: 22-6$

[27] Johnson RJ, Kang DH, Feig D, Kivilighn S, Kanelis J, Watanbe $\mathrm{S}$, et al. Is there a pathogenetic role for uric acid in hypertension and cardiovascular and renal disease? Hypertension 2003;41(6):1183-1190
[28] Mumford SL, Dasharathy SS, Pollack AZ, Perkins NJ, Cole SR, Wactawski-Wende J, et al. Serum uric acid in relation to endogenous reproductive hormones during the menstrual cycle: findings from the BioCycle study. Human Reproduction 2013;28(7):1853-1862

[29] Daoussis D, Panoulas V, Toms T, John H, Antonopoulos I, Nightingale $\mathrm{P}$, et al. uric acid is a strong independent predictor of renal dysfunction with rheumatoid arthritis. Arthritis Research and Therapy 2009; 11: R116.

[30] Tian Y, Chen Y, Deng B, Lui G, Ji ZG, Zhao QZ, et al. Serum uric acid as an index of impaired renal function in congestive heart failure. Journal of Geriatric Cardiology 2012; 9:137-142.

[31] Anderson RF, Harris TA. Dopamine and uric acid acts as antioxidants in the repair of Parkinson's disease. Free Radical Research 2003; 37: 1131-6.

[32] Scott GS, Cuzzocrea S, Genovese T, Koprowski H, Hooper DC Uric acid protects against secondary damage after spinal cord injury. Proceedings of National Academy of Science USA 2005; 102: $3483-8$.

[33] Ejaz AA, Mu W, Kang DH, Roncal C, Sautin YY, Henderson G, et al. Could uric acid have a role in acute renal failure? Clinical Journal American Society of Nephrology, 2007;2:16-19

[34] Hooper DC, Spitsin S, Kean RB, Champion JM, Dickson GM, Chaudhry I, et al. Uric acid, a natural scavenger of peroxynitrite, in experimental allergic encephalomyelitis and multiple sclerosis. Proceedings of National Academy of Science USA 1998; 95: 675-680.

[35] Mattle HP, Lienert C, Greere I. Uric acid and multiple sclerosis. Journal: Ther Umsch 2004; 61(4):533-5.

[36] Anker SD, Doehner W, Rauchhaus M, Sharma R, Francis D, Knosalla C, et al. Uric acid and survival in congestive heart failure: validation and application in metabolic, functional and hemodynamic staging. Circulation 2003; 107:1991-1997

[37] Cengel A, Turkoglu S, Turfan M, Boyaci B. Serum uric acid levels as a predictor of in-hospital death in patients hospitalized for decompensated heart failure. Acta Cardiologica 2005; 60:489-492.

[38] Lee SM, Lee AL, Winters TJ, Tam E, Jaleel M, Stenvinkel P, Johnson RJ. Low serum uric acid levels are a risk factor for death in incident hemodialysis patients. American Journal of Nephrology 2009; 29:79-85

[39] Kastenbauer S, Koedel U, Becker BF, Pfister HW. Experimental meningitis in rats: protection by uric acid at human physiological blood concentrations. European Journal of Pharmacology 2001; 425: 149-52.

[40] Glynn RJ, Campion EW, Silbert JE. Trends in serum uric acid levels 1961-1980. Arthritis \& Rheumatology 1983; 26:87-93

[41] Grayson PC, Kim SY, LaValley M, Choi KH. Hyperuricemia and incident hypertension: a systemic review and meta-analysis Arthritis Care Research (Hoboken) 2011; 63(1):102-110. doi: 10.1002/acr.20344.

[42] Richette P, Bardin T. Gout. Lancet 2010; 375:318-328

[43] Roddy E, Doherty M. Epidemiology of gout. Arthritis Research \& Therapy $2010,12: 223$. 
[44] Nan H. Serum uric acid and metabolic risk factors in three ethnic groups: Asian Indians and Creoles in Mauritius and Chinese in Qingdao, China. Academic Dissertation. Helsinki, 2008. Accessed on 23 March 2014 at http://helda.helsinki.fi/bitstream/handle/10138/20371/serumur i.pdfsequence $=1$ ?

[45] Colleton BF. Uric acid and cardiovascular disease: a renal cardiac relationship? Current Opinions in Nephrology and Hypertension 2001; 10:371-375

[46] Pagana K, Pagana T. Mosby's diagnostic and laboratory test reference. $9^{\text {th }}$ edition. St Louis, MO: Mosby, Inc, 2009:957

[47] Jeanin G, Chiarelli N, Gaggiotti M, Ritteli M, Maiorca P, Quinzani FV, et al. Recurrent exercise-induced acute induced renal failure in a young Pakistani man with severe renal hypouricemia and SLC2A9 compound heterozygosity. BMC Medical Genetics 2014; 15(3):1-8. http://www.biomedcentral.com/ 1471-2350/15/3

[48] Stiburkova B, Ichida K, Sabesta I. Novel homozygous insertion in SLC2A9 gene caused renal hypouricemia. Molecular Genetics and Metabolism 2011; 102(4): 430-5.

[49] Stiburkova B, Taylor J, Marinaki AM, Sebesta I. Acute kidney injury in two children caused by renal hypouricemia type 2 . Pediatric Nephrology 2012; 27(8): 1411-5.

[50] Anton FM, Garcia Puig J, Ramos T, Gonzalez P, Ordas J. Sex differences in uric acid metabolism in adults: evidence for a lack of influence of estradiol-17 beta (E2) on the renal handling of urate. Metabolism 1986; 35: 343-8.

[51] Wingrove CS, Walton C, Stevenson JC. The effects of menopause on serum uric acid levels in non-obese healthy women. Metabolism 1998; 47:435-8.

[52] Beavers KM, Beavers DP, Serra MC, Bowden RG, Wilson RL. Low relative skeletal muscle mass indicative of sarcopenia is associated with elevations in serum uric acid levels: findings from NHANES III. The Journal of Nutrition, Health \& Aging. 2009; 13(9):177.

[53] Sutton JR, Toews CJ, Ward GR, Fox IH. Purine metabolism during strenuous muscular exercise in man. MetabolismClinical and Experimental 1980; 29:254-260.

[54] Green HJ, Fraser IG. Differential effects of exercise intensity on serum uric acid concentration. Medicine \& Science in Sport \& Exercise 1988; 20:55-59.

[55] Sjodin B, Hellsten-Westing Y. Changes in plasma concentration of hypoxanthine and uric acid in man with short-distance running at various intensities. International Journal of Sport Medicine 1990; 11:493-495.

[56] Huang LL, Huang CT, Chen ML, Mao IF. Effects of profuse sweating induced by exercise on urinary uric acid excretion in a hot environment. Chinese Journal of Physiology 2010; 53(4):254-261.

[57] Nakamura A, Niima R, Yanagawa Y. Renal hypouricemia in school-aged children: screening of serum uric acid levels before physical training. Pediatric Nephrology 2006; 21(12): 1898-900.

[58] Mima A, Ichida K, Matsubara T, Kanamori H, Inui E, Tanaka $\mathrm{M}$, et al. Acute renal failure after exercise in a Japanese sumo wrestler with renal hypouricemia. American Journal of the Medical Sciences 2008; 336(6): 512-4.
[59] Woo J, Swaminathan R, Cockram C, Lau E, Chan A. Association between serum uric acid and some cardiovascular risk factors in a Chinese population. Postgradate Medical Journal 1994; 70, 486-491.

[60] Nan H, Dong Y, Gao W, Toumilethto J, Qiao Q. Diabetes associated with a low serum uric acid level in a general Chinese population. Diabetes Research and Clinical Practice 2007; 76 (1):68-74.

[61] Maynard W, Janet A, Mc Adams A, Mara NN, Baer Alan C, Josef $\mathrm{C}$ et al. Racial differences in gout risk and uric acid levels in both men and women in atherosclerosis risk in community (ARIC) study. Arthritis and Rheumatism 2010; 62(10): 1556.

[62] De Boer MD, Dong L, Gurka MJ. Racial/ethnic and gender differences in the relationship between uric acid and metabolic syndrome in adolescents: an analysis of NHANES 1999-2006. Metabolism 2012; 61 (4): 554-561.

[63] Chang HY, Pan WH, Yeh WT, Tsai KS. Hyperuricemia and gout in Taiwan: results from the nutritional and health survey in Taiwan (1993-1996). Journal of Rheumatology 2001; 28:1640-6.

[64] Wortman RL. Gout and hyperuricemia. Current Opinions in Rheumatology 2002; 14:281-6.

[65] Liu L, Luo S, Xu K, Meng Z, Zhang Q, Song K. Relationship between lifestyle choices and hyperuricemia in Chinese men and women. Clinical Rheumatology 2012; 23(2):233-9.

[66] Ogino K, Hisatome I, Saitoh M, Miyamoto J, Ishiko R, Hasegawa J, Mashiba H. Clinical significance of hypouricemia in hospitalized patients. Journal of Medicinal Chemistry 1991; 22(2):76

[67] Ramdell CM, Kelley WN. The clinical significance of hypouricemia. Annals of Internal Medicine 1973; 78(2): 239-242.

[68] Maesaka JK, Fishbane S. Regulation of renal urate excretion: a critical review. American Journal of Kidney Disease 1998; 32: 917-933.

[69] Chizynski K, Rozycka M. Hyperuricemia. Pol Mekur Lekarshi (in Polish). 2005; 19(113):693-42.

[70] Garg JP, Chasan-taber S, Blair A, Pione M, Bommer J, Raggi P, et al. Effects of sevelamer and calcium-based phosphate binders on uric acid concentrations in patients undergoing hemodialysis: a randomized clinical trials. Arthritis and Rheumatism 2005; 52(1):290-5.

[71] Maesaka JK, Batuman V, Yudd M, Salem M, Sved AF, Venkatesan J. Hyponatriemia and Hypouricemia: differentiation from SIADH. Clinical Nephrology 1990: 33(4):174-8.

[72] Izumi N, Hasumura Y, Takeuchi J. Hypouricemia and hyperuricosuria as expressions of renal tubular damage in primary biliary cirrhosis. Hepatology, 1983: 3(5):719-23

[73] Fenske W, Stork S, Koscher AC, Blechschmidt A., Lorenz D, Wortmann S, Allilio B. Value of fractional uric acid excretion in differential diagnosis. Journal of Clinical Endocrinology and Metabolism 2008; 93(8): 2991-2997.

[74] Jacome MA, Uehera SK, Monteiro WL, de Maria CA, Rosa G. Effects of green coffee beans extracts in some biomarkers of adult brazilian subjects. Alimentos e Nutricao Araraquara 2009; 20(2):185-190. 
[75] Kiyohara C, Kono S, Honjo S, Todoroki I, Sakurai Y, Nishiwaki M, et al. Inverse association between coffee drinking and serum uric acid concentrations in middle-aged Japanese males. British Journal of Nutrition 1999; 82:125-130.

[76] Seiner R, Hesse A. The effect of a vegetarian and different omnivorous diet on urinary risk factors for uric acid stone formation. European Journal of Nutrition 2003; 42(6):332-7.

[77] Szeto YT, Kwok TC, Benzie IF. Effects of a long-term vegetarian diet on biomarkers of antioxidants status and cardiovascular disease risk. Nutrition 2004; 20(10):863-6.

[78] Koretz RL. Hypouricemia-a transient biochemical phenomenon of total parenteral nutrition. American Journal of Clinical Nutrition 1981; 34(11): 2493-8.

[79] Derus CL, Levinson DJ, Bowson B, Bengoa JM, Sitrin MD. Altered fractional excretion of uric acid during total parenteral nutrition. Journal of Rheumatology 1987; 14(3):978-81.

[80] Moyer RA, John DS. Acute gout precipitated by total parenteral nutrition. Journal of Rheumatology 2003; 30(4): 849-50.

[81] Ichida K, Hosoyamada M, Hisatome I, Enomoto A, Hikita M, Endou H. 2004. Clinical and molecular analysis of patients with renal hypouricemia in Japan: influence of URAT1 gene on urinary urate excretion. Journal of American Society of Nephrology 15:164-73.

[82] Takahashi T, Tsuchida S, Oyamada T, Ohno T, Miyashita M, Saito S, Komatsu K, et al. Recurrent URAT1 gene mutations and prevalence of renal hypouricemia in Japanese. Pediatrics Nephrology 2005; 20(5):576-8.

[83] Wakida N, Tuyen DG, Adachi M, Miyoshi T, Nonoguchi H, Oka $\mathrm{T}$, et al. Mutations in human urate transporter 1 gene in presecretory reabsorption defect of familial renal hypouricemia. Journal of Clinical Endocrinology and Metabolism 2005; 90(4):2169-74.

[84] Esparza NM, Nieto GV. Hypouricemia and tubular transport of uric acid. Nefrologia 2011;31(1):44-50

[85] Enomoto A, Kimura H, Chairoungdua A, Shigeta Y, Justabha P, $\mathrm{Cha} \mathrm{SH}$, et al. Molecular identification of a renal urate anion exchanger that regulates blood urate levels. Nature 2002; 417:447-52.

[86] Komoda F, Sekine T, Inatomi J, Enomoto A, Endou H, Oka T, et al. 2004. The W258X mutation in SLC22A12 is the predominant cause of Japanese renal hypouricemia. Pediatric Nephrology 2004; 19:728-33.

[87] Liote F. Hyperuricemia and gout. Current Rheumatology Reports 2003; 5:227-234.

[88] Holmes EW, Wyngarden JB. Hereditary xanthinuria In: Scriver CD, Beaudet AL, Sly WS, Valle D, editors, The metabolic basis of inherited diseases, $6^{\text {th }}$ ed, Mc Graw Hill, New York, 1989.

[89] Levartovsky D, Lagziel A, Sperling O, Liberman U, Yaron M, Hosoya T, Ichida K, Peretz H. XDH gene mutation the underlying cause of xanthinuria, a second report. Kidney International 2000; 57(6):2215.

[90] Church WH, Ward VL. Uric acid is reduced in the substantia nigra in Parkinson's disease: effect on dopamine oxidation. Brain Research Bulletin 1994; 33:419-425.

[91] Toncev G, Milicic B, Toncev S, Samardzic G. Serum uric acid levels in multiple sclerosis patients correlated with activity of disease and blood-brain-barrier dysfunction. European Journal of Neurology 2002; 9:221-6.

[92] Pitocco D, di Stasio E, Rometelli F, Zaccardi F, Tavazzi B, Manto A, et al. Hypouricemia linked to an overproduction of nitric oxide is an early marker of oxidative stress in female subjects with type 1 diabetes. Diabetes/Metabolism Research and Review 2008; 24(4):318-23.

[93] Devuyst O, Igarashi T. Renal Fanconi syndrome, Dent's disease and Barter's syndrome. In: Thankker RV, Whyte MP, Eisman JA, Igarashi T, editors. Genetics of bone biology and skeletal disease, New York: Elsevier/Press; 2012, p 553-67.

[94] Waring WS, Webb DJ, Maxwell SRJ. Uric acid as a risk factor for cardiovascular disease. QJM: an International Journal of Medicine 2000; 93:707-13.

[95] Tian Y, Chen Y, Deng B, Lui G, Ji ZG, Zhao QZ, Zhen YZ, et al. Serum uric acid as an index of impaired renal function in congestive heart failure. Journal of Geriatric Cardiology 2012; 9:137-142.

[96] See LC, Kuo CF, Chang FH, Shen YM, Ko YS, Chen YM, et al. Hyperuricemia and metabolic syndrome: associations with chronic kidney disease. Clinical Rheumatology 2011; 30:323-330.

[97] Cain L, Shankar A, Ducatman AM, Steenland K. The relationship between serum uric acid and chronic kidney disease among Appalachian adults. Nephrology Dialysis Transplantation 2010; 25:3593-99.

[98] Causevic A, Semiz S, Macic-Dzankovic A, Cico B, Dujic T, Malencia M, et al. Relevance of uric acid in the progression of type 2 diabetes mellitus. Bosnian Journal of Basic Medical Sciences 2010; 10(1):54-59.

[99] Aarfolt T, Bruusgaard D. Chronic musculoskeletal complaints and subgroups with special reference to uric acid. Scandinavian Journal of Rheumatology, 1994; 23:25-29

[100] Brule D, Sarwar G, Savoie L. Changes in serum urinary uric acid levels in normal human subjects fed purine-rich foods containing different amounts of adenine and hypoxanthine. The Journal of American College of Nutrition, 1992; 11(3):353-8.

[101] Loenen HM, Eshius H, Lowik MR, Schouten EG, Hulsof KF, Odink J, Kok FJ. Serum uric acid correlates in the elderly men and women with special reference to body composition and dietary intake (Dutch nutrition surveillance system). Journal of Clinical Epidemiology 1990; 43:1297-303.

[102] Choi HK, Liu S, Curhan G. Intake of purine-rich foods, protein, and dairy products and relationship to serum levels of uric acid: the Third National Health and Nutrition Examination Survey. Arthritis \& Rheumatism 2005; 52: 283-9.

[103] Hernig M, Johnson RJ. Role of uric acid in hypertension, renal disease and metabolic syndrome. Cleverland Clinic Journal of Medicine 2006; 73(12): 1059-61.

[104] Miller A, Adeli K. Dietary fructose and the metabolic syndrome. Current Opinions in Gastroenterology 2008; 24(2):204-9.

[105] Choi JW, Ford ES, Gao X, Choi HK. Sugar-sweetened soft drinks, diet soft drinks and serum uric acid level: the third national health and nutrition examination survey. Arthritis \& Rheumatism 2008; 59(1):109-16. 
[106] Nakagawa T, Hu H, Zharikov S, Tuttle KR, Short RA, Johnson $\mathrm{RJ}$, et al. The causal role for uric acid in fructose-induced metabolic syndrome. American Journal of Physiology: Renal Physiology 2006; 290(3):F625-31.

[107] Hallfrish J. Metabolic effects of dietary fructose. FASEB Journal 1990; 4:2652-60.

[108] Mayes PA. Intermediary metabolism of fructose. American Journal of Clinical Nutrition 1993; 58:754S-65S.

[109] Champe PC, Harvey RA, Ferrier R. Lippincott's Illustrated Reviews: Biochemistry. $2^{\text {nd }}$ edition. Philadelphia: Lippincott Willams \& Wilkins: 1994: 253-55.

[110] Le KA, Tappy L. Metabolic effects of fructose. Current Opinions in Clinical Nutrition and Metabolic Care 2006; 9:469-75.

[111] Vitart V, Rudan I, Hayward C, Gray NK, Floyd J, Palmer CN, et al. SLC2A9 is a newly identified urate transporter influencing serum urate concentration, urate excretion and gout. Nature Genetics 2008; 40(4):437-42.

[112] Wrolstad RE, Shallenberger RS. Free sugar and sorbitol in fruits- a complication from the literature. Journal-Association of Official Analytical Chemistry 1981; 64:91-103.

[113] Johnson RJ, Perez-Pozo SE, Sautin YY, Manitus J, Sanchez-Lozada LG, Feig D, et al. Hypothesis: could excessive fructose intake and UA cause type 2 diabetes? Endocrinology Reviews 2009;30(1): 96-116

[114] Macdonald I, Keyser A, Pacy D. Some effects in man of varying the load of glucose, sucrose, fructose or sorbitol on various metabolites in blood. American Journal of Clinical Nutrition 1978; 31(8): 1305-1311.

[115] Emmerson BT. Effects of oral fructose on urate production. Annals of Rheumatic Diseases 1974; 33(3):276-280.

[116] Fox IH, Kelley WH. Studies on the mechanism of fructose-induced hyperuricemia in man. Metabolism 1972; 21:713-721.

[117] Crapo PA, Kolterman OG. The metabolic effects of two weeks fructose feeding in normal subjects. American Journal of Clinical Nutrition 1984; 39(4): 523-534.

[118] Huttenen JK, Makinen KK, Scheinin A. Turku sugar studies XI. Effects of sucrose and xylitol diet on glucose and urate metabolism. Acta Odontologica Scandinavica 1976; 34(6):345-51.

[119] Curreri PW, Pruitt BA Jr. Absence of fructose-induced hyperuricemia in men. Lancet 1970; 1:839.

[120] Osei K, Bosseti B. Dietary fructose as a natural sweetener in poorly controlled type 2 diabetes: a 12 month crossover study of the effects on glucose, lipoprotein, and apolipoprotein metabolism. Diabetic Medicine 1989; 6(6): 506-511.

[121] Anderson JW, Story LZ, Zeltwoch NC, Gustafson NJ, Jefferson BS. Metabolic effects of fructose supplementation in diabetics individuals. Diabetes Care 1989; 12(5):337-344.

[122] Koh ET, Ard NF, Mendoza F. Effects of fructose feeding on blood parameters and blood pressure in impaired glucose-tolerant subjects. Journal of the American Dietetic Association 1988; 88(8):930-38.

[123] Grigoresco C, Rizkalla SW, Halfton P, Bornet F, Frontvielle
$\mathrm{AM}$, Bros $\mathrm{M}$, et al. lack of detectable deleterious effects on metabolic control of dietary fructose ingestion for 2 mo in NIDDM. Diabetes Care 1988; 11(7): 546-50.

[124] Sun SZ, Flickinger BD, Williamson-Hughes PS, Empie MW. Lack of association between dietary fructose and hyperuricemia risk in adults. Nutrition \& Metabolism 2010; 7:16. doi: 10.1186/1743-7075-7-16.

[125] Lyu LC, Hsu CY, Yeh CY, Lee MS, Huang SH, Chen CL. A case-control study of the association of diet and obesity with gout Taiwan. American Journal of Clinical Nutrition 2003; 78: 690-701.

[126] Yu KH, See LC, Huang YC, Yang CH, Sun JH. Dietary factors associated with hyperuricemia in adults. Seminars in Arthritis and Rheumatism 2008; 37; 243:-50.

[127] Gibson T, Rodgers AV, Simmonds HA, Toseland P. Beer drinking and its effects on uric acid. British Journal of Rheumatology 1984; 23: 203-9.

[128] Yamamoto T, Moriwaki Y, Takahashi S. Effect of ethanol on metabolism of purine bases (hypoxanthine, xanthine and uric acid). Clinica Chimica Acta; International Journal of Clinical Chemistry 2005; 356(1-2):35-37.

[129] Faller J, Fox IH. Ethanol-induced hyperuricemia: urate production by activation of adenine nucleotide turnover. The New England Journal of Medicine: Research \& Reviews 1982; 307: 1598-02

[130] Sharpe CR. A case-control study of alcohol consumption and drinking behavior in patients with acute gout. Canadian Medical Association Journal 1984; 131:563-7.

[131] Drum DE, Goldman PA, Jankowski CB. Elevation of serum uric acid as a clue to alcohol abuse. Archives of Internal Medicine 1981; 141: 477-9.

[132] Eastmond CJ, Garton M, Robbins S, Riddoch S. The effects of alcoholic beverages on urate metabolism in gout sufferers. British Journal of Rheumatology 1995; 34: 756-9.

[133] Sclensinger N. Dietary factor and hyperuricemia. Current Pharmacological Design 2005; 11:4139-43.

[134] Roky R, Houti I, Moussamih S, Qotbi S, Aadil N. Physiological and chronobiological changes during Ramadan intermittent fasting. Annals of Nutrition and Metabolism 2004; 48:296-303.

[135] Ames BN, Cathcart R, Schewiers E, Hochstein P. Uric acid provides an antioxidant defense in humans against oxidant-and radical-caused aging and cancer: a hypothesis. Proceedings of the National Academy of Science USA 1981; 78:6858-6862.

[136] Hayden MR, Tyagi SC. Uric acid: a new look at an old risk marker for cardiovascular, metabolic syndrome and type 2 diabetes mellitus: the urate redox shuttle. Nutrition \& Metabolism (London) 2004;1:10

[137] Proctor PH. Uric acid: neuroprotective or neurotoxic? Stroke 2008; 39:e88.

[138] Many A, Hubel CA, Roberts JM. Hyperuricemia and xanthine oxidase in preeclampsia revisited. American Journal of Obstetrics and Gynecology 1996; 174:288-91.

[139] Sautin YY, Johnson RJ. Uric acid: the oxidant-antioxidant paradox. Nucleosides Nucleotides Nucleic Acids 2008; 27(6):608-19. 
[140] Lam C, Lim KH, Kang DH, Karumanchi SA. Uric and preeclampsia. Seminars in Nephrology 2005; 25(1):56-60.

[141] Renzos M, Nikolaou C, Anagnostouli M, Rombos A, Tsakanikas K, Economou M, et al. Serum uric acid and multiple sclerosis. Clinical Neurology and Neurosurgery 2006; 108(6):527-31.

[142] Sautin YY, Imaram V, Kim KM, Angerhofer A, Henderson G, Johnson R. Chapter 8: Uric acid and oxidative stress. In: Miyata T, Eckhart KN, Nangaku M, editorsm. Studies in renal disorders. Oxidative stress in applied basic research practice. Springer Science + Business Media LLC, 2011. doi : 10.1007/987-1-60761-857-7-7_8

[143] Corry DB, Eslami P, Yamamoto K, Nyby MD, Makino H, Tuck ML. Uric acid stimulates vascular smooth muscle cell proliferation and oxidative stress via the vascular renin-angiotensin system. Journal of Hypertension 2008; 26: 269-275.

[144] Knapp CM, Constantinescu CS, Tan JH, McLean R, Cherryman GR, Gottlob I. Serum uric acid levels in optic neuritis. Multiple Sclerosis 2004; 10:270-80.

[145] Shen L, Ji HF. Low uric acid levels in patients with Parkinson's disease: evidence from meta-analysis. BMJ Open 2013 3: e0003620

[146] Erley CM, Hirschberg RR, Hoefer W. Acute renal failure due to uric acid nephropathy in a patient with renal hypouricemia. Kliniche Wochenschr 1989; 67 (5): 308-312.

[147] Stiburkova B, Ichida K, Sebesta I. Novel homozygous insertion in SLC2A9 gene caused renal hypouricemia. Molecular Genetics and Metabolism 2011; 102(4): 430-435.

[148] Stiburkova B, Taylor J, Marinaki AM, Sebesta I. acute kidney injury in two children caused by renal hypouricemia type 2 . Pediatric Nephrology 2012; 27(8): 1411-1415

[149] Sperling O. Hereditary renal hypouricemia. In: Scriver CD, Beaudet AL, Sly WS, Valle D, editors. The metabolism and metabolic basis of inherited disease, New York: Mc Graw Hill; 2001; 5069-84.

[150] Dinour D, Bahn A, Ganon L, Rom R, Geifman-Holtzman O, Knetcht A, et al. URAT1 mutations cause renal hypouricemia type 1 in Iraqi Jews. Nephrology Dialysis Transplant 2010. doi: 10. 1093/ndt/gfq722.

[151] Wu XW, Muzny DM, Lee CC, Caskey CT. Two independent mutational events in the loss of urate oxidase during homoniod evolution. Journal of Molecular Evolution 1992; 34:78-84.

[152] Schwalfenberg GK. The alkaline diet: is there evidence that an alkaline $\mathrm{pH}$ diet benefits health? Journal of Environmental and Public Health 2012, article ID 727630, 1-7. doi:10.115/2012/727630.

[153] Frassetto LA, Morris Jr RC, Sellmayer DE, Todd K, Sebastian A. Diet, evolution and aging-the pathophysiologic effects of the post agricultural inversion of the potassium-to-sodium and base-to-chloride ratios in the human diet. European Journal of Nutrition, 2001; 40(5): 200-213.

[154] Sebastian A, Frassetto LA, Sellmayer DE, Merriam RL, Morris Jr RC. Estimation of net acid load in the diet of ancestral pre-agricultural homosapiens and their hominid ancestors. American Journal of Clinical Nutrition 2001; 76(6):1308-16.
[155] Linderman RD, Goldman R. Anatomic and physiologic age changes in the kidney. Experimental Gerontology 1986; 21(4-5):379-406.

[156] Kanbara A, Miura Y, Hyogo H, Chayama K, Seyama I. Effect of urine $\mathrm{pH}$ changed by dietary intervention on uric acid clearance mechanism of $\mathrm{pH}$-dependent excretion of urinary uric acid. Nutrition Journal 2012; 11:39.

[157] Choi HK, Curhan G. Coffee, tea and caffeine consumption and serum uric acid levels: the third National Health and Nutrition Examination survey. Arthritis \& Rheumatism 2007; 57:816-21.

[158] de Oliveira EP, Moreto F, de Arruda Silveira LV, Burini RB. Dietary, anthropometric and biochemical determinants of uric acid in free-living adults. Nutrition Journal 2013; 12:11. $\mathrm{http}: / / w w w . n u t r i t i o n j . c o m /$ content/ 12/1/11

[159] Yu TF. Milestone in the management of gout. The American Journal of Medicine 1974; 56(5):676-85.

[160] Lee SM, Lee AL, Winters TJ, Tam E, Jaleel M, Stenvinkel P, Johnson RJ. Low serum uric acid levels are a risk factor for death in incident hemodialysis patients. American Journal of Nephrology 2009; 29:79-85.

[161] Sautin YY, Nakagawa T, Zharikov S, Johnson RJ. Adverse effects of the classical antioxidant uric acid in adipocytes: NADPH oxidase-mediated oxidative/nitrosative stress. American Journal of Physiology 2007; 293:C584-C596.

[162] Mazzali M, Kanelis J, Han L, Feng L, Xia YY, Chen Q, et al. Hyperuricemia induces a primary renal arteriolopathy in rats by a blood pressure-independent mechanism. American journal of physiology: Renal physiology 2002; 282:F991-7.

[163] Johnson RJ, Segal MS, Srinivas TR, Ejaz A, Mu W, Roncal $\mathrm{C}$, et al. Essential hypertension, progressive renal disease and uric acid: a pathogenetic link. Journal of American Society of Nephrology 2005; 16:1909-19.

[164] Kang DH, Nakagawa T, Feng L, Watanbe S, Han L, Mazzali M, et al. A role of uric acid in the progression of renal disease. Journal of American Society of Nephrology 2006; 17:S69-S73. doi:10.1681/ASN.2005121331.

[165] Hovind P, Rossing P, Parving HH. Serum uric acid as a new player in the development of diabetic nephropathy. Journal of Renal Nutrition 2011; 21(1):124-7.

[166] Tanaka K, Hara S, Hattori M, Sakai K, Onishi Y, Yoshida Y, et al. Role of elevated serum uric acid levels at onset of overt nephropathy in the risk of renal function decline in patients with type 2 diabetes. Journal of Diabetes Investigation 2014. doi $: 10.1111 / \mathrm{jdl} .12243$.

[167] Mohandas R, Johnson RJ. Uric acid levels increase risk for new-onset kidney disease. Journal of American Society of Nephrology 2008; 19:2251-2253.

[168] Filipoulos V, Hadjiyannoakos D, Viassopoulos D. New insights into uric acid effects on the progression and prognosis of chronic kidney disease. Renal Failure, 2012; 34(4):510-20.

[169] Horsfall LJ, Nazareth I, Petersen I. Serum uric acid and the risk of respiratory disease: a population-based cohort study. Thorax 2014;0:1-6

[170] Bartziokas K, Papaioannou AI, Loukides S, Papadopoulos A, Haniotou A, Papiris S, et al. Serum uric acid as a predictor of mortality and future exacerbation of COPD. European Respiratory Journal. 2014; 43(1): 43-53. 
[171] Wu VC, Huang JW, Hsueh PR, Yang Yf, Tsai HB, Tsai HB, et al, SARS Research group of the National Taiwan University college of medicine and national Taiwan university hospital. Renal hypouricemia is an ominous sign in patients with severe acute respiratory syndrome. American Journal of Kidney Diseases 2005; 45(1): 88-95.

[172] Akahosi T, Murakami Y, Kitasoato H. Recent advances in crystal induced acute inflammation. Current Opinions in Rheumatology 2007; 19(2):146-50.

[173] Shi Y, Musci AD, Ng B. Monosodium crystals in inflammation and immunity. Immunological Reviews 2010; 233(1):203-17.

[174] Martinon F, Pertrilli V, Mayor A, Tardivel Tschopp J. Gout-associated uric acid crystals activate the NAPL3 inflammasome. Nature 2006; 440(7081):237-41.

[175] Paganoni S, Zhang M, Quiroz Zarate A, Jaffa M, Yu H, et al. Uric acid levels predict survival in men with amyotrophic lateral sclerosis. Journal of Neurology 2012; 259:1923-8.

[176] Andreadou E, Nikolaou C, Gournaras F, Renzos M, Boufidou F, Vassilopoulos D, et al. Serum uric acid levels in patients with Parkinson's disease : their relationship to treatment and disease duration. Clinical Neurology and Neurosurgery 2009; 111:724-8.

[177] Auinger P, Kietburtz K, Mc Dermott MP. The relationship between uric acid levels and Huntington's disease progression. Movement Disorders 2010; 25:224-8.

[178] Messerli FH, Frolisch ED, Dreslinki GR, Suarez DH,
Aristimuno GG. Serum uric acid in essential hypertension: an indicator of renal vascular involvement. Annals of Internal Medicine, 1980; 93: 817-21.

[179] Rao GN, Corson MA, Berk BC. Uric acid stimulates smooth muscle proliferation by increasing platelet-derived growth factor A-chain expression. The Journal of Biological Chemistry 1991; 226:8604-08.

[180] Franco M, Tapia E, Santamaria J, Zafra I, Garcia-Torres R, Gordon KL, et al. Renal cortical vasoconstriction contributes to the development of salt-sensitive hypertension after angiotensin II exposure. Journal of American Society of Nephrology 2001; 12: 2263-71.

[181] Johnson RJ, Herrera- Acosta J, Schreiner GF, Rodriguez-iturbe B. Subtle acquired renal injury as a mechanism of salt-sensitive hypertension. The New England Journal of Medicine 2002; 346:913-23

[182] Bo S, Cavallo-Perin P, Gentile L, Repetti E, Pagano G. Hypouricemia and hyperuricemia in type 2 diabetes: two different phenotypes. European Journal of Clinical Investigation 2001;31(4):318-21.

[183] Watanbe S, Kang Dh, Nakagawa T, Kanellis J, Lan H, Mazzali M, Johnson RJ. Uric acid, homonoid evolution and salt sensitivity. Hypertension 2002; 40:355-60.

[184] Manfredi RM, Mastroianni A, Coronado OV, Chiodo F. Hyperuricemia and the progression of HIV disease. Journal of Acquired Immunodeficiency Syndrome and Human Virology $1996 ; 12(3): 318-19$ 